\title{
Analyzing the Perceptions of Egyptian Youth about the Arab Spring
}

\section{CIRANO}

Allier savoir et décision

ALI FAKIH

PASCAL L. GHAZALIAN 
2019s-21

\title{
Analyzing the Perceptions of Egyptian Youth about the Arab Spring
}

\author{
Ali Fakih, Pascal L. Ghazalian
}

Série Scientifique

Scientific Series

\author{
Montréal \\ Octobre/October 2019
}

(C) 2019 Ali Fakih, Pascal L. Ghazalian. Tous droits réservés. All rights reserved. Reproduction partielle permise avec citation du document source, incluant la notice C. Short sections may be quoted without explicit permission, iffull credit, including (C) notice, is given to the source.

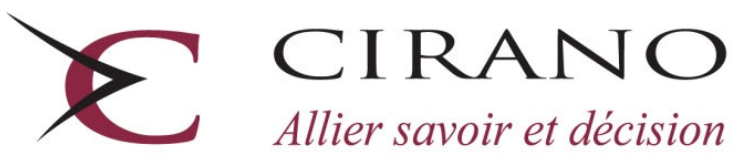

Centre interuniversitaire de recherche en analyse des organisations 


\section{CIRANO}

Le CIRANO est un organisme sans but lucratif constitué en vertu de la Loi des compagnies du Québec. Le financement de son infrastructure et de ses activités de recherche provient des cotisations de ses organisations-membres, d'une subvention d'infrastructure du gouvernement du Québec, de même que des subventions et mandats obtenus par ses équipes de recherche.

CIRANO is a private non-profit organization incorporated under the Quebec Companies Act. Its infrastructure and research activities are funded through fees paid by member organizations, an infrastructure grant from the government of Quebec, and grants and research mandates obtained by its research teams.

\section{Les partenaires du CIRANO}

\section{Partenaires corporatifs}

Autorité des marchés financiers

Banque de développement du Canada

Banque du Canada

Banque Laurentienne

Banque Nationale du Canada

Bell Canada

BMO Groupe financier

Caisse de dépôt et placement du Québec

Canada Manuvie

Énergir

Hydro-Québec

Innovation, Sciences et Développement économique Canada

Intact Corporation Financière

Investissements PSP

Ministère de l'Économie, de la Science et de l'Innovation

Ministère des Finances du Québec

Mouvement Desjardins

Power Corporation du Canada

Rio Tinto

Ville de Montréal

\section{Partenaires universitaires}

École de technologie supérieure

École nationale d'administration publique

HEC Montréal

Institut national de la recherche scientifique

Polytechnique Montréal

Université Concordia

Université de Montréal

Université de Sherbrooke

Université du Québec

Université du Québec à Montréal

Université Laval

Université McGill

Le CIRANO collabore avec de nombreux centres et chaires de recherche universitaires dont on peut consulter la liste sur son site web.

Les cahiers de la série scientifique (CS) visent à rendre accessibles des résultats de recherche effectuée au CIRANO afin de susciter échanges et commentaires. Ces cahiers sont écrits dans le style des publications scientifiques. Les idées et les opinions émises sont sous l'unique responsabilité des auteurs et ne représentent pas nécessairement les positions du CIRANO ou de ses partenaires.

This paper presents research carried out at CIRANO and aims at encouraging discussion and comment. The observations and viewpoints expressed are the sole responsibility of the authors. They do not necessarily represent positions of CIRANO or its partners. 


\title{
Analyzing the Perceptions of Egyptian Youth about the Arab Spring
}

\author{
Ali Fakih * Pascal L. Ghazalian ${ }^{*}$
}

\begin{abstract}
Résumé
Egyptian youth played a central role in the Arab Spring (AS) uprisings, yearning for changes in the political system and for better economic conditions. This paper investigates the perceptions of young Egyptians about the AS. The empirical analysis uses a bivariate ordered probit model to examine the factors influencing these perceptions through proxies that cover political, social, and economic conditions. The results reveal that social values and ideological characteristics matter more than the standard socioeconomic attributes in understanding the perceptions of young Egyptians. They indicate that individuals with secularist, non-traditionalist, and gender equality inclinations formed more favourable perceptions about the AS. Also, they suggest that the AS has led to unfavourable perceived circumstances for the Arab Nationalism and pan-Islamism ideologies, and propitious perceived conditions for further connection with the global system. These findings signal that the AS may have set a path toward a significant transformation in the Egyptian society.
\end{abstract}

Keywords/Mots-clés: Arab Spring, Egypt, Youth, Perceptions, Social Change, Bivariate Ordered Probit

\footnotetext{
* Associate Professor, Department of Economics, Lebanese American University, Beirut, Lebanon, P.O.Box: 135053. E-mail: afakih@lau.edu.lb.

$\dagger$ Associate Professor, Department of Economics, University of Lethbridge, Lethbridge, Alberta, Canada, T1K 3M4. E-mail: pascal.ghazalian@uleth.ca.
} 


\section{Introduction}

Self-immolating is not a common incident in the Arab World where the dominant religion is Islam, which prohibits any act of suicide (Lesch \& Haas, 2016). This situation drastically changed in 2010, when a young Tunisian vendor, Mohamed Bouazizi, immolated himself after Tunisian police confiscated the few goods he had been selling. The police justified their action by curbing illegal practices in the country (Anderson, 2011). This incident was the catalyst of massive protests that erupted across the country, leading to the deposition of the long-standing dictator, Zine El-Abidine Ben Ali. The 2010's Tunisian revolution turned out to be the sparkle of what has been later known as the Arab Spring (AS). ${ }^{1}$ The AS waves reached Egypt where massive protests broke out in January 2011, paving the way for Egypt's first revolution in decades and eventually deposing its de facto dictator Hosni Mubarak.

Egypt has had a rough transition from deposing Mubarak to democratically electing its first post-revolution president, Mohammad Morsi, who belongs to the conservative Muslim Brotherhood, in 2010 (Marfleet, 2016). ${ }^{2,3}$ Empowered by their expanding influence, the Muslim Brotherhood sought to expand their power by invoking the Sharia Law in the articles of the new constitution (Marfleet, 2016). Massive protests erupted against the Muslim Brotherhood rule in 2013. Eventually, the Egyptian army deposed Mohamed Morsi, and announced a new transitional period of twelve months. Abdel

\footnotetext{
${ }^{1}$ The AS is a set of uprisings across the Middle East and North Africa (MENA) region. The "Spring" terminology is an allusion to the "Spring of Nations", which characterizes a series of political upheavals that stroke Europe in 1848. These upheavals stemmed from waves of democracy movements that were often liberal in nature.

${ }^{2}$ The Muslim Brotherhood is a transnational Islamism organization founded by Muslim scholars in Egypt in 1928 for the primary goal of promoting political activism under Islamic ideology. It is worth noting that Muslim Brotherhood's activities are strictly prohibited in several MENA countries.

${ }^{3}$ The Muslim Brotherhood managed to gain a simple majority in the Egyptian parliamentary elections, making the Muslim Brotherhood the most powerful political party that controls both the legislative and executive powers of the state.
} 
Fattah El-Sisi, the president of the Military Council became a front runner, ultimately winning the Egyptian presidential election in $2014 .^{4}$

Egypt was susceptible to AS movements due to an alarming unemployment level (particularly among young Egyptians), increasing dissatisfaction with the long-standing political regime, and unprecedented rises in food and energy prices (Acar \& Dogruel, 2012; Winckler, 2013; Rougier, 2016). In spite of having an average Gross Domestic Product (GDP) growth rate of around 5\%, Egypt has constantly suffered from aggravated economic discrepancies, and rampant political oppression. ${ }^{5}$ Costello et al. (2015) indicate that state terror, besides demands for bread, justice, and political opportunities, significantly contributed in igniting the AS uprisings in Egypt and in other MENA countries. Egypt's susceptibility to AS movements was also fueled by the dismal job that the government has been doing in serving the population, especially young people (Winckler, 2013; Verme et al., 2014). Devarajan \& Ianchovichina (2018) shed light on the increasing pre-AS dissatisfaction with the quality of public services, the shortage of formal-sector jobs, and corruption. They underline that the old social contract was already broken on the eve of the AS. ${ }^{6}$

The youth of Egypt played a vital role through the AS event (LaGraffe, 2012; Paciello \& Pioppi, 2016; UNDP, 2016). Hoffman \& Jamal (2012) describe the AS event as a youth rebellion against the political status quo and unemployment. They indicate that the participating young Egyptians in the AS uprisings are often characterized as being less religious and more likely to be unemployed, but they may not necessarily hold secularist inclinations and dissatisfaction with the old authoritarian regime. Bayat (2013) finds that the participants in the AS uprisings came from different ideological and

\footnotetext{
4 The contemporary history of Egypt is full of turning points (see El-Samman, 2012). Also, see Frisch (2013) and Hamid (2014) for an overview of Egypt's politics and political structure.

${ }^{5}$ Hassine (2015) notes that there is a considerable variation in income level and income inequality across the AS countries, with Egypt standing at a comparatively low-income low-inequality position. It is therefore difficult to determine whether there exists a causal effect of income inequality on the occurrence of AS uprisings.

${ }^{6}$ Glasius \& Pleyers (2013) note that contemporary waves of uprisings, including the AS movements, are often characterized by demands for democracy, social justice, and dignity.
} 
political backgrounds, including pious Muslims, secularists, and nationalists. ${ }^{7} \mathrm{He}$ also underlines that many young participants displayed religious rituals through the uprisings, without the intention to Islamize the revolution. Sayed (2013) characterizes the young Egyptians who enthusiastically participated in the revolution, as being less likely to join liberal political parties. This is because these parties are often perceived to be non-transparent and lacking a clear political mandate. Acemoglu et al. (2017) indicate that the AS protests were primarily organized by middle-class young Egyptians, ${ }^{8}$ and that the AS event led to a redistribution of political power and eventually mattered for the economic outcome as expressed through the curtailment of politically-connected firms in Egypt.

Campante \& Chor (2012) link the AS event to the "youth bulge", 9 which accompanied increases in educated individuals and diploma-holders facing low economic opportunities. ${ }^{10}$ They note that inadequate opportunities for well-educated youth tend to accelerate political incidents, such as regime instability and political change. ${ }^{11}$ Mulderig (2013) indicates that young Egyptians harboured frustrations due to significant obstacles in fulfilling the social contract of adulthood (e.g., education, employment, and marriage/family formation), eventually motivating them to get engaged in resentment-driven protests. Also, Rougier (2016) implies that the AS uprisings were motivated by the growing wedge between youth's aspirations to climb the social ladder and the narrow economic opportunities that resulted from a slow structural change in the economy and from the inadequate

\footnotetext{
${ }^{7}$ Abdelrahman (2009) points out the pre-AS collaboration between various political groups with differing political ideologies in forming an opposition front vis-à-vis Mubarak's regime.

${ }^{8}$ Kuhn (2012) mentions that urban young Egyptians aptly used social media, promoting the collective action through the AS uprisings.

${ }^{9}$ Also, Singerman (2013) notes that the "youth bulge", which came about with high unemployment levels and obstacles facing marriage, has forced young individuals to express their frustrations through the AS protests. Costello et al. (2015) do not find, however, a statistically significant evidence that the "youth bulge" per se is a key factor in stirring the AS uprisings.

${ }^{10}$ Karshenas et al. (2014) underline the prevalence of skills mismatch as a contributing factor to high unemployment levels and, hence, to the AS uprisings.

${ }^{11}$ In this context, Kuhn (2012) underlines the role of human development factor in reshaping the relationship between citizens and state, and in catalyzing the AS event.
} 
performance of MENA governments in terms of development policies. ${ }^{12}$ Ghanem (2018) notes that the general exclusion-feeling among young Egyptians in the decision-making processes that affect their well-being was a supplementary factor in motivating them to participate in the AS protests. ${ }^{13}$

Being active participants in the AS event, young Egyptians expressed their goals and aspirations through the AS protests, yearning for significant economic and political reforms and occasionally for drastic social changes. Naturally, they formed perceptions about government, public institutions, and political life through the pre-AS and post-AS periods. ${ }^{14}$ Several studies underline the role of socioeconomic elements and the significance of cultural and ideological factors in defining and formulating the perceptions of individuals about various political and social events and issues. For instance, Nogee \& Levin (1958) inspect the determinants of political perceptions among college youth in Boston, and find that political attitudes and perceptions are contingent on several factors including age, religious affiliation, socio-economic status, parents' political views, and political ideology. Conover (1984, 1988) finds that group identifications ${ }^{15}$ play a significant role in formulating the perceptions of individuals on politics in the United States, and she explains that people identified with different groups tend to evaluate political issues and events from different perspectives. Granberg (1985) indicates that education, gender, religious association, party preference, and political ideology are important determinants of individuals' perceptions on the abortion issue in the United States prior to the 1980 presidential election. Caprara et al. (1999) examine the relationships between the characteristics of

\footnotetext{
${ }^{12}$ Beck \& Hüser (2012) note that education, rentier economy, economic affluence, economic liberalization, and media tend to substantially influence political perception and political stability, particularly among youth.

${ }^{13}$ Assaad \& Barsoum (2007) highlight the restrictions imposed on political discourse and student activities by the security apparatus in Egypt over the last decades.

${ }^{14}$ Anderson (2011) indicates that the AS event generated a post-AS wave of political optimism among the Arab youth. Refaei (2015) discusses that Egyptians place more credence in voting and political participation than in violently changing the status quo, and that the majority of Egyptians consider political participation as being necessary to maintain a functional political system. He also implies that Egyptians tend to be low-spirited when it comes to the post-AS political system and to the prospect of any possible improvement.

${ }^{15}$ Conover (1984, p. 761) notes that "Most treatments of the concept of group identification incorporate the idea of a psychological tie to some social stratum or more formal group".
} 
Italian voters and their political party preferences, and they find that personality traits rather than the standard socio-economic factors (e.g., gender, age, and education) are the main predictors of political preferences. Also, Vecchione \& Caprara (2009) find that personality traits and socio-demographic factors have important implications for political efficacy and political participation in Italy. Schoon \& Cheng (2011) notice that political perceptions in the United Kingdom are often shaped by individuals' family background, school motivation, cognitive ability at early age, and schooling and professional life in adulthood.

This paper aims at providing novel empirical insights on the factors influencing the perceptions of Egyptians about the AS, by focusing on the youth population. We use a unique dataset extracted from the SAHWA Youth Survey, which was carried out in 2016. The perceptions of the Egyptian youth about the AS are depicted using various proxies, covering freedom of speech, political participation, political influence of citizens, corruption control, non-fear of arrest, rule of law, and economic performance. The dependent variables distinctively consist of pre-AS and post-AS perception variables. The explanatory variables are classified into two main sets. The first set includes youth's socio-economic attributes, while the second set covers youth's value-based characteristics. The empirical analysis is carried out using a bivariate ordered probit model, which allows to jointly examine the determinants of the youth's perceptions before and after the AS event. The remainder of this paper is organized as follows. Section 2 describes the data and variables used through the empirical analysis. Section 3 displays the empirical model and discusses the econometric methodology. Section 4 presents and discusses the empirical results, and Section 5 provides concluding remarks and policy recommendations.

\section{Data and Variables}

We use a micro-level dataset extracted from the SAHWA Youth Survey that was carried out in 2016. This is a unique and rich multi-country survey conducted by the SAHWA Project, covering five major 
MENA countries. ${ }^{16}$ The empirical analysis is implemented for a random sample of 1,970 young Egyptian respondents. This sample is statistically formed to be nationally representative of Egyptian youth aged between 15 and 29 years old. The survey is designed to randomly select a young respondent from each targeted household, and the analysis is carried out at the individual level. ${ }^{17}$

The questionnaire covers a variety of themes on youth perceptions including: (1) Freedom of Speech (FS), which measures the level of individual and collective freedom in regards to publically expressing ideas, opinions, and thoughts; (2) Political Participation (PP), which reflects the extent of Egyptian youth participation in different types of political activities, such as elections (municipal, parliamentary, and presidential), and any sort of active participation in the political sphere; (3) Political Influence of Citizens (PI), which signifies to what extent the youth can influence the political sphere in Egypt through political parties (and their respective political ideologies), organizations, and institutions, inter alia; (4) Corruption Control (CC), which reflects the perceived control level of public institutions' graft rampant, including nepotism, favouritism, and bribery; (5) Non-Fear of Arrest (NFA), which inversely encompasses the extent of fear of being arrested or prosecuted on political/noncriminal grounds; (6) Rule of Law (RL), which designates the amount of confidence that the youth places in the efficiency of implementing the rule of law (primarily covering the prevention of crime and the maintenance of order) in Egypt; and (7) Economic Performance (EP), which covers the perception of the youth about the economic situation and about the relevant economic challenges and opportunities. The empirical investigation is implemented through a bivariate ordered probit model (discussed in the next section) to estimate the determinants of the Egyptian youth's perceptions about

\footnotetext{
${ }^{16}$ The SAHWA Project (www.sahwa.eu) is an interdisciplinary cooperative research project led by the Barcelona Centre for International Affairs (CIDOB) and funded by the European Commission. It brought together fifteen partners from Europe and Southern and Eastern Mediterranean countries to research youth prospects and perspectives in a context of multiple social, economic, and political transitions in five Arab countries (Algeria, Egypt, Lebanon, Morocco, and Tunisia).

${ }^{17}$ It is worth mentioning that missing data is coded as "not applicable" without distinguishing between the categories of "refusals", "no answer", and "don't know".
} 
the AS. The aforementioned seven proxies that capture the perceptions of Egyptian youth are depicted as ordinal dependent variables with three discrete categories $(1,2$, and 3$)$, where a higher value reflects a more favourable perception.

The explanatory variables used in the regressions are classified into two main sets. The first set includes basic socio-economic attributes of the respondents. It covers gender (Male), which is a binary variable that equals one for the corresponding respondent and that equals zero otherwise, Age that is defined in years, and Income that is defined in terms of the monthly salary in US dollars. This set also covers education, which is captured through three binary variables: i) No Education, that equals one if the respondent did not receive any sort of formal education and that equals zero otherwise (this is set as the reference education variable in the empirical model), ii) School, that equals one if the respondent has a pre-school, primary, or secondary education and that equals zero otherwise, and iii) University, that equals one if the respondent has a university degree and that equals zero otherwise. Marital status is introduced through the binary variable Married. The employment status of the respondent is controlled through the binary variable Employed. The first set of variables also comprises the binary variable Urban Residence, which takes into account whether the respondent resides in an urban area or a rural area.

The second set of the explanatory variables contains value-based characteristics of the respondents, covering ideologically-driven tendencies, and cultural and social values. This set includes the ordinal variable Secularist with three discrete categories $(0,1$, and 2$)$, where a higher value indicates a more favourable perception about separating religion/religious institutions and state/governmental institutions, and that public activities and decisions, especially political ones, should not be influenced by religious beliefs or practices. The ordinal variable Gender Equality Proponent with three discrete categories $(0,1$, and 2$)$ reflects the tendency to place credence in gender equality, taking a higher value when the respondent favours equality between men and women in the society. Non-Traditionalist is a 
binary variable that reflects beliefs in the applicability of modern values against more traditional social norms and rules. It equals one if the respondent indicates that tradition (in terms of following the norms and rules established by society and religion) is not important, and it equals zero otherwise.

The second set also covers cultural self-identity perceptions of the respondents. The following binary variables of self-identity perceptions are included in the empirical model: Global when the respondent claims to culturally belong to the global/international community), Arab when the respondent claims to culturally belong to the Arab world, and Islamic when the respondent claims to culturally belong to the Islamic Ummah (i.e., Islamic community). These self-identity perception variables are not mutually exclusive (for example, the respondent can be simultaneously self-identified as culturally belonging to the Arab world and to the Islamic Ummah). The reference individual is the Egyptian respondent who is not self-identified by either of these categories. Finally, the ordinal variable Ambitious with four discrete ordinal categories $(0,1,2$, and 3$)$ characterizes the respondents' aspirations in terms of the importance of being innovative and prosperous in the society, and it could coarsely overlap with the entrepreneurial tendencies of the respondents.

Table 1 presents descriptive statistics of the dependent variables before and after the AS. These statistics show that the majority of the respondents have generally reported unfavourable perceptions through the pre-AS period. They also reveal some improvements in the perceptions of the Egyptian youth in the post-AS period, particularly through the variables Freedom of Speech, Political Participation, and Rule of Law, where 45\%,44\%, and 48\% of the surveyed individuals reported highly favourable perceptions (i.e., category 3), respectively. Meanwhile, the statistics generally reflect less favourable perceptions about Political Influence of Citizens, Non-Fear of Arrest, and Economic Performance through the post-AS period.

Table 2 shows descriptive statistics of the explanatory variables used in the empirical model. The means of the ordinal variables Secularist and Gender Equality Proponent are above one (on a 
discrete scale of 0 to 2), indicating relatively higher tendencies for respondents to be proponents of secularism and gender equality in the sample. Also, the descriptive statistics indicate that only $9.1 \%$ of the surveyed Egyptian youth claim to be non-traditionalist. The statistics on self-identity show that $7.0 \%$ of youth perceive themselves to be global citizens, while $11.5 \%$ and $10.1 \%$ perceive themselves to culturally belong to the Arab world and to the Islamic Ummah, respectively. The mean of the ordinal variable Ambitious stands at 2.1 (on a discrete scale of 0 to 3). The descriptive statistics on the socioeconomic factors show that around half of the respondents in the sample are males, and that the average age is around 22 years. The mean of the monthly income is relatively low partly because it covers several responses of zero income (e.g., respondents who are unemployed or not participating in the labour market). Also, the statistics on education show that $4.9 \%$ of the respondents do not have any sort of formal education, while $70.5 \%$ of them have a pre-school, primary, or secondary education, and $24.6 \%$ of them have a university education.

\section{Econometric Methodology}

Given the ordered nature of the dependent AS perception variables, the empirical analysis relies on the ordered probit model to estimate the equations. The perceptions of the surveyed individuals about the pre-AS and post-AS situations are expected to exhibit correlation and, therefore, the corresponding equations are jointly estimated using the bivariate ordered probit model, which is an extension of the standard bivariate probit model where the dependent categories are more than two. Let $y_{i}^{\text {pre* }}$ and $y_{i}^{\text {post* }}$ depict the corresponding pre-AS and post-AS latent variables, respectively. Also, let $v_{i}$ represent a vector that includes subjective value-based characteristics (e.g., political views/ideology, cultural identity, gender equality), and let $s_{i}$ represent a vector containing socio-economic characteristics of the surveyed individuals (e.g., marital status, income, education), respectively. Then, we get: 


$$
\left\{\begin{array}{l}
y_{i}^{\text {pre* }}=\alpha^{\text {pre }}+v_{i}^{\prime} \beta^{\text {pre }}+s_{i}^{\prime} \gamma^{\text {pre }}+\varepsilon_{i}^{\text {pre }}=z_{i}^{\text {pre }}+\varepsilon_{i}^{\text {pre }} \\
y_{i}^{\text {post }}=\alpha^{\text {post }}+v_{i}^{\prime} \beta^{\text {post }}+s_{i}^{\prime} \gamma^{\text {post }}+\varepsilon_{i}^{\text {post }}=z_{i}^{\text {post }}+\varepsilon_{i}^{\text {post }}
\end{array}\right.
$$

where $\beta^{\text {pre }}, \beta^{\text {post }}, \gamma^{\text {pre }}$, and $\gamma^{\text {post }}$ are the vectors of parameters, and where $\varepsilon_{i}^{\text {pre }}$ and $\varepsilon_{i}^{\text {post }}$ follow a bivariate standard normal distribution. The latent variables are converted into observable categorical variables $y_{i}^{\text {pre }}$ and $y_{i}^{\text {post }}$ with discrete ordinal values of 1,2, and 3. Letting the threshold levels in the pre-AS equation be denoted by $\zeta_{1}^{\text {pre }}$ and $\zeta_{2}^{\text {pre }}$, and letting those in the post-AS equation be denoted by $\zeta_{1}^{\text {post }}$ and $\zeta_{2}^{\text {post }}$, we get:

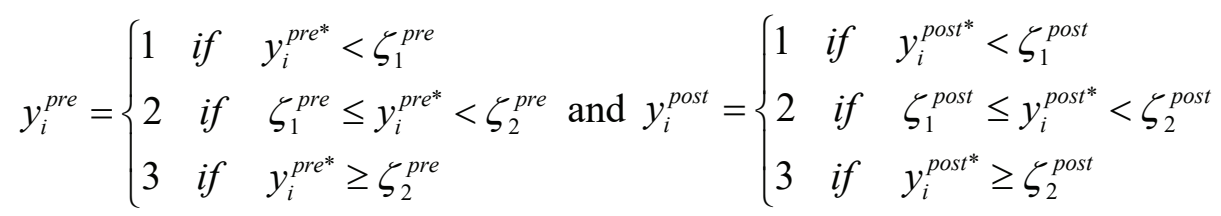

Let $\Phi_{2}(\cdot)$ depict the bivariate standard normal distribution function, and let $\rho$ represent the correlation between $\varepsilon_{i}^{\text {pre }}$ and $\varepsilon_{i}^{\text {post }}$. The univariate probabilities of $y_{i}^{\text {pre }}=a$ (with $a=1,2,3$ ) and $y_{i}^{\text {post }}=b($ with $b=1,2,3)$ are respectively given by:

$$
\begin{aligned}
& \operatorname{Pr}\left(y_{i}^{\text {pre }}=a\right)=\Phi\left(\zeta_{a}^{\text {pre }}-z_{i}^{\text {pre }}\right)-\Phi\left(\zeta_{a-1}^{\text {pre }}-z_{i}^{\text {pre }}\right), \text { and } \\
& \operatorname{Pr}\left(y_{i}^{\text {post }}=b\right)=\Phi\left(\zeta_{b}^{\text {post }}-z_{i}^{\text {post }}\right)-\Phi\left(\zeta_{b-1}^{\text {post }}-z_{i}^{\text {post }}\right)
\end{aligned}
$$

The joint probability of $y_{i}^{\text {pre }}=a$ and $y_{i}^{\text {post }}=b$ is determined as:

$$
\begin{aligned}
\operatorname{Pr}\left(y_{i}^{\text {pre }}=a, y_{i}^{\text {post }}=b\right)= & \Phi_{2}\left(\zeta_{a}^{\text {pre }}-z_{i}^{\text {pre }}, \zeta_{b}^{\text {post }}-z_{i}^{\text {post }}, \rho\right)-\Phi_{2}\left(\zeta_{a-1}^{\text {pre }}-z_{i}^{\text {pre }}, \zeta_{b}^{\text {post }}-z_{i}^{\text {post }}, \rho\right) \\
& -\Phi_{2}\left(\zeta_{a}^{\text {pre }}-z_{i}^{\text {pre }}, \zeta_{b-1}^{\text {post }}-z_{i}^{\text {post }}, \rho\right)+\Phi_{2}\left(\zeta_{a-1}^{\text {pre }}-z_{i}^{\text {pre }}, \zeta_{b-1}^{\text {post }}-z_{i}^{\text {post }}, \rho\right)
\end{aligned}
$$

The following log-likelihood function is maximized to estimate the parameters, including the thresholds and $\rho$ (Sajaia, 2008; Greene \& Hensher, 2010; Greene, 2012):

$$
\ln L=\sum_{i} \sum_{a} \sum_{b} \kappa\left(y_{i}^{\text {pre }}=a, y_{i}^{\text {post }}=b\right) \times \ln \operatorname{Pr}\left(y_{i}^{\text {pre }}=a, y_{i}^{\text {post }}=b\right)
$$


where $\kappa\left(y_{i}^{\text {pre }}=a, y_{i}^{\text {post }}=b\right)$ equals one if the surveyed individual $i$ responded by $y_{i}^{\text {pre }}=a$ and by $y_{i}^{\text {post }}=b$, and it equals zero otherwise. The estimation procedure uses the derivative of the loglikelihood function with respect to each coefficient. The Likelihood Ratio (LR) test is implemented to examine the null hypothesis of independent equations (i.e., $\rho=0$ ) versus the alternative hypothesis of correlated equations (i.e., $\rho \neq 0) .{ }^{18}$ To simplify the mathematical representation, let $\varpi=\left(1-\rho^{2}\right)^{1 / 2}$, $\zeta_{a}^{\text {pre }}-z_{i}^{\text {pre }}=\delta_{i, a}^{\text {pre }}, \zeta_{a-1}^{\text {pre }}-z_{i}^{\text {pre }}=\delta_{i, a-1}^{\text {pre }}, \zeta_{b}^{\text {post }}-z_{i}^{\text {post }}=\delta_{i, b}^{\text {post }}$, and $\zeta_{b-1}^{\text {post }}-z_{i}^{\text {post }}=\delta_{i, b-1}^{\text {post }}$. The joint marginal effects of a given variable in the pre-AS equation $\left(v_{i}^{\text {pre }}\right)$ and the post-AS equation $\left(v_{i}^{\text {post }}\right)$ are respectively determined as (Greene \& Hensher, 2010; Greene, 2012):

$$
\begin{gathered}
\frac{\partial \operatorname{Pr}\left(y_{i}^{\text {pre }}=a, y_{i}^{\text {post }}=b\right)}{\partial v_{i}^{\text {pre }}}=\left(-\beta_{v^{p r e}}\right)\left\{\begin{array}{l}
\phi\left(\delta_{i, a}^{\text {pre }}\right) \Phi_{2}\left[\frac{\left(\delta_{i, b}^{\text {post }}-\rho \delta_{i, a}^{p r e}\right)}{\varpi}\right]-\phi\left(\delta_{i, a-1}^{\text {pre }}\right) \Phi_{2}\left[\frac{\left(\delta_{i, b}^{\text {post }}-\rho \delta_{i, a-1}^{\text {pre }}\right)}{\varpi}\right] \\
-\phi\left(\delta_{i, a}^{\text {pre }}\right) \Phi_{2}\left[\left(\frac{\delta_{i, b-1}^{\text {post }}-\rho \delta_{i, a}^{\text {pre }}}{\varpi}\right)\right]+\phi\left(\delta_{i, a-1}^{\text {pre }}\right) \Phi_{2}\left[\frac{\left(\delta_{i, b-1}^{\text {post }}-\rho \delta_{i, a-1}^{\text {pre }}\right)}{\varpi}\right]
\end{array}\right\} \\
\frac{\partial \operatorname{Pr}\left(y_{i}^{\text {pre }}=a, y_{i}^{\text {post }}=b\right)}{\partial v_{i}^{\text {post }}}=\left(-\beta_{v^{\text {post }}}\right)\left\{\begin{array}{l}
\phi\left(\delta_{i, b}^{\text {post }}\right) \Phi_{2}\left[\frac{\left(\delta_{i, a}^{\text {pre }}-\rho \delta_{i, b}^{\text {post }}\right)}{\varpi}\right]-\phi\left(\delta_{i, b-1}^{\text {post }}\right) \Phi_{2}\left[\frac{\left(\delta_{i, a}^{\text {pre }}-\rho \delta_{i, b-1}^{\text {post }}\right)}{\varpi}\right] \\
-\phi\left(\delta_{i, b}^{\text {post }}\right) \Phi_{2}\left[\left(\frac{\delta_{i, a-1}^{\text {pre }}-\rho \delta_{i, b}^{\text {post }}}{\varpi}\right)\right]+\phi\left(\delta_{i, b-1}^{\text {post }}\right) \Phi_{2}\left[\frac{\left(\delta_{i, a-1}^{\text {pre }}-\rho \delta_{i, b-1}^{\text {post }}\right)}{\varpi}\right]
\end{array}\right\}
\end{gathered}
$$

When the same variable appears in both equations, the two components are simply added. Finally, the conditional marginal effects are presented as (Greene \& Hensher, 2010; Greene, 2012):

\footnotetext{
${ }^{18}$ Other tests can be also used, including the Wald test and the GMM-based test of Butler \& Chatterjee (1995). If the error terms $\varepsilon_{i}^{\text {pre }}$ and $\varepsilon_{i}^{\text {post }}$ are independent and normally distributed, the pre-AS and post-AS equations can be estimated using the univariate ordered probit estimator.
} 


$$
\begin{aligned}
& \partial \operatorname{Pr}\left(y_{i}^{\text {pre }}=a \mid y_{i}^{\text {post }}=b\right) / \partial v_{i}^{\text {pre }}=\frac{\partial \operatorname{Pr}\left(y_{i}^{\text {pre }}=a, y_{i}^{\text {post }}=b\right) / \operatorname{Pr}\left(y_{i}^{\text {pre }}=a\right)}{\partial v_{i}^{\text {pre }}} \\
& =\frac{\partial \operatorname{Pr}\left(y_{i}^{\text {pre }}=a, y_{i}^{\text {post }}=b\right) / \partial v_{i}^{\text {pre }}}{\operatorname{Pr}\left(y_{i}^{\text {pre }}=a\right)}-\operatorname{Pr}\left(y_{i}^{\text {post }}=b \mid y_{i}^{\text {pre }}=a\right) \frac{\phi\left(\delta_{i, a}^{\text {pre }}\right)-\phi\left(\delta_{i, a-1}^{\text {pre }}\right)}{\operatorname{Pr}\left(y_{i}^{\text {pre }}=a\right)}\left(-\beta_{v^{\text {pre }}}\right){ }^{\text {and }} \\
& \partial \operatorname{Pr}\left(y_{i}^{\text {pre }}=a \mid y_{i}^{\text {post }}=b\right) / \partial v_{i}^{\text {post }}=\frac{\partial \operatorname{Pr}\left(y_{i}^{\text {pre }}=a, y_{i}^{\text {post }}=b\right) / \operatorname{Pr}\left(y_{i}^{\text {pre }}=a\right)}{\partial v_{i}^{\text {post }}} \\
& =\frac{\partial \operatorname{Pr}\left(y_{i}^{\text {pre }}=a, y_{i}^{\text {post }}=b\right) / \partial v_{i}^{\text {post }}}{\operatorname{Pr}\left(y_{i}^{\text {pre }}=a\right)}
\end{aligned}
$$

where $\operatorname{Pr}\left(y_{i}^{\text {pre }}=a\right)=\Phi\left(\delta_{i, a}^{\text {pre }}\right)-\Phi\left(\delta_{i, a-1}^{\text {pre }}\right)$. Again, the two components are added when the same variable appears in both equations.

\section{Empirical Results}

Table 3 through Table 9 show the estimated coefficients of the pre-AS and post-AS perception equations from the bivariate ordered probit model, and present the corresponding unconditional marginal effects. One notable feature of these tables is that the estimated coefficients on the variables associated with individuals' socio-economic characteristics are mostly non-statistically significant with few exceptions. In contrast, the estimated coefficients on the value-based variables more frequently exhibit statistical significance in the pre-AS and post-AS equations. These results suggest that the perceptions of the surveyed young Egyptians are principally driven by their values and ideological backgrounds rather than by their standard socio-economic characteristics. Accordingly, the following discussion of the empirical results focuses on the value-based variables. Also, Table A1 through Table A4 of the Appendix display the corresponding joint marginal effects. Given that the estimated coefficients on the socio-economic variables are mostly non-statistically significant, these supplementary tables exclusively display the joint marginal effects of the value-based variables. 


\subsection{Secularists}

The estimated coefficients on the Secularist variable are positive and statistically significant in some pre-AS equations, and they are positive and statistically significant in all post-AS equations. These results imply that the perceptions of individuals who hold inclinations toward secularism on the proxied political and economic issues had been in some cases more favourable before the AS period compared to the reference less-secularist individuals. The more favourable perceptions of more secularist individuals are strengthened following the AS event, and prevail through all the proxies. The unconditional marginal effects indicate that the farthest secularist individuals (i.e., Secularist=2) and the least secularist (or non-secularist) individuals (i.e., Secularist $=0$ ) have equivalent perceptions on political participation, freedom of speech, and rule of law in the pre-AS period, ceteris paribus. In comparison, secularist individuals developed more favourable perceptions vis-à-vis non-secularist individuals in the post-AS period through these proxies. For instance, the unconditional probabilities of $P P=3, F S=3$, and $R L=3$ are higher by $2 \times 5.1=10.2,2 \times 4.9=9.8$, and $2 \times 3.8=7.6$ percentage points for the farthest secularist individuals compared to the least secularist individuals, respectively, ceteris paribus.

Also, the unconditional marginal effects indicate that individuals with secularist inclinations have more favourable perceptions on political influence of citizens, non-fear of arrest, and corruption control in the pre-AS period, which become moderately strengthened in the post-AS period. For example, in the cases of the unconditional marginal effects for $P I=3, F A=3$, and $C C=3$, the results suggest that the perceptions of the farthest secularist individuals compared to those of the least secularist individuals are more favourable by $4.0,5.1$, and 4.8 percentage points in the pre-AS period, which increase to $7.8,10.6$, and 12.0 percentage points in the post-AS period, respectively, ceteris paribus. The perception of secularist individuals on the economic performance is also more favourable compared to less secularist individuals. For instance, the unconditional marginal effect of the farthest 
secularist individuals on $E C=3$ stands at 5.6 percentage points in the pre-AS period, increasing to 9.4 percentage points in the post-AS period.

\subsection{Gender Equality Proponents}

The estimated coefficients on the Gender Equality Proponent variable show that the corresponding individuals have experienced improvements in some of their perceptions on gender equality status in Egypt following the AS event. For instance, the unconditional marginal effects of the gender equality variable on political participation and political influence of citizens do not exhibit statistical significance in the pre-AS period, indicating statistically equivalent perceptions of gender equality proponents and those of other individuals with lower inclinations toward gender equality. In contrast, these marginal effects become positive and statistically significant in the post-AS period. The unconditional probabilities of $P P=3$ and $P I=3$ for individuals expressing the strongest adherence to the gender equality principle (i.e., Gender Equality Proponent=2) are higher by $2 \times 8.0=16.0$ and $2 \times 2.8=5.6$ percentage points compared to individuals expressing the weakest adherence to the gender equality principle (i.e., Gender Equality Proponent=0), respectively, ceteris paribus. ${ }^{19}$

The estimated coefficients in both the pre-AS and the post-AS equations are not statistically significant in the cases of freedom of speech, rule of law, corruption control, and economic performance. These results indicate that the perceptions of individuals belonging to the different categories of gender equality adherence levels are statistically equivalent in both the pre-AS and the post-AS periods. The results also indicate that individuals who are adherent to the gender equality principle tend to fear less political/non-criminal arrest compared to those that are less adherent to this

\footnotetext{
${ }^{19}$ Al-Ali (2012) underlines the significant role of women in the AS uprisings, which naturally tends to stimulate moves toward gender equality. Our results highlighting improvements in the perceptions of gender equality proponents in the post-AS period are arguably consistent with these initial observations. Also, Moghadam (2013, 2014) concludes that genuine AS-related social transformations and democratization in the MENA region is not feasible without effective participation of women in the economy and in politics.
} 
principle. For instance, the unconditional marginal effect for $N F A=3$ indicates that individuals expressing the strongest adherence to the gender equality principle have more favourable perceptions by 4.6 percentage points in the pre-AS period, that increase to 8.8 percentage points in the post-AS period, ceteris paribus.

\subsection{Non-Traditionalists}

The estimated coefficients on the Non-Traditionalist variable are found to be negative and statistically significant at the $1 \%$ level across all the pre-AS equations. Meanwhile, those in the post-AS equations are found to be positive and statistically significance at the $1 \%$ level, except in the case of rule of law and corruption control where the corresponding estimates are not statistically significant. These results are consistent with the occurrence of structural changes in the traditional Egyptian society following the AS event. They reveal significant improvements in the perceptions of individuals who are less adherent (or not adherent) to Egypt's conventional social norms and traditions (i.e., NonTraditionalist $=1$ ) vis-à-vis those that are more adherent to them (i.e., Non-Traditionalist $=0$ ). In the preAS period, the unconditional marginal effects for $P P=3, P I=3, F S=3$, and $N F A=3$ are negative and statistically significant. They indicate that non-traditionalist individuals have less favourable perceptions on political participation, political influence of citizens, freedom of speech, and living without fear of political/non-criminal arrest compared to traditionalist individuals by $9.5,5.7,11.4$, and 7.0 percentage points, respectively, ceteris paribus. In the post-AS period, the corresponding marginal effects become positive and statistically significant, revealing that non-traditionalists have more favourable assessments compared to traditionalists by $6.59 .5,11.3$, and 7.7 percentage points, respectively, ceteris paribus. ${ }^{20}$

\footnotetext{
${ }^{20}$ In this context, Al-Ali (2012) indicates that militarized masculinity, which characterized the pre-AS Egypt, tends to undermine women and non-normative men. Hence, the AS uprisings, which appear to moderately reduce the intensity of this pre-AS feature, would arguably promote the post-AS perceptions of women and non-traditionalist individuals.
} 
The unconditional marginal effects for $R L=3$ and $C R=3$ are negative and statistically significant in the pre-AS period, showing less favourable perceptions of non-traditionalists on rule of law and corruption control compared to traditionalists by 15.8 and 8.4 percentage points, respectively, ceteris paribus. While these marginal effects are not statistically significant in the post-AS period, they suggest nonetheless relative improvements in the perceptions of non-traditionalists following the AS event.

In contrast, the perceptions of non-traditionalists on the economy are found to be less favourable compared to the perceptions of traditionalists in both the pre-AS and post-AS periods. The corresponding unconditional marginal effects are negative and statistically significant, standing at -9.9 and -6.6 percentage points, respectively, ceteris paribus.

\subsection{Cultural Self-Identity}

There are three cultural self-identity variables in the empirical model, where surveyed individuals identify themselves by the following potential identities: (i) Arab identity (in terms of cultural belonging to the Arab world), which is consistent with the Arab Nationalism ideology and inclinations, and which is expressed through the ideology of some political parties such as, the Arab Democratic Nasserist Party (al-Hizb al-'Arabi al-Dimuqrati al-Nasseri) and, to some extent, by Hosni Mubarak's dissolved National Democratic Party (Al-Hizb Al-Wațan̄̄ Ad-Dìmūqrāț̣̂̀); (ii) Islamic identity (in terms of cultural belonging to the Islamic Ummah), which coarsely encompasses political Islamic inclinations, and which is expressed through the ideology of some prominent political parties such as, the Muslim Brotherhood (al-Ikhwān al-Muslimūn) and Salafist groups including the Party of the Light (Hizb al-Nūr); ${ }^{21}$ and (iii) Global identity (in terms of cultural belonging to the global/international community), which is typically consistent with favourable views on international integration, liberalism, and cultural and trade openness, and which is in conformity with the basic ideology and

\footnotetext{
${ }^{21}$ Islamist parties and groups assumed varying political positions following the AS event. See Al-Anani (2012), AlAnani \& Malik (2013), and Volpi \& Stein (2015) for a review.
} 
inclinations of some political parties such as, the Constitution Party (Hizb el-Dostour) founded by Mohamed El-Baradei, the Nobel Peace Prize Laureate.

The estimated coefficients on Self-Identity: Arab in the pre-AS equations are found to be mostly positive and statistically significant at the $1 \%$ level, except in the case of non-fear of arrest (nonstatistically significant coefficient). These results indicate more favourable perceptions on Egypt's political and socio-economic situations in the pre-AS period. However, the estimates reveal that these favourable perceptions have relatively decreased in the post-AS period. For instance, the unconditional marginal effects show that individuals who are self-recognized by their cultural Arab identity have more favourable views in the pre-AS equations on political participation for $P P=3$ and on freedom of speech for $F S=3$ by 14.5 and 14.8 percentage points, respectively, compared to the reference individuals, ceteris paribus. However, they experience a decline in the post-AS equations. These transformations could be driven by the post-AS political, social, and cultural changes, which could have relatively lessened the strength of the cultural Arab identity and/or the status of the Arab Nationalism ideology vis-à-vis other composite identities of Egyptians.

The estimated coefficients on Self-Identity: Islamic in the pre-AS equations are mostly not statistically significant, and become negative and statistically significant in the post-AS period. These results could be indicative of moderate shifts that are brought about by the AS against political power and social values of individuals who are particularly adherent to the religion and religious principles. A notable illustration can be depicted through the quick rise of the Muslim Brotherhood to power shortly after ousting Mubarak, and by its quick and significant decline after the massive protests that led to the ousting of Mohamed Morsi in 2013. For instance, the unconditional marginal effects indicate that individuals who are culturally self-recognized by their religion and the corresponding reference individuals have statistically equivalent perceptions on political influence of citizens for $P I=3$ and rule of law for $R L=3$ in the pre-AS period. The unconditional marginal effects of the first group experience 
relative decreases in the post-AS period, becoming negative and statistically significant at the $1 \%$ level

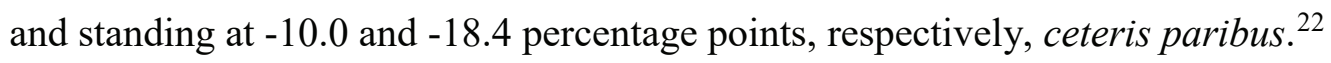

The estimated coefficients on Self-Identity: Global in the pre-AS equations are found to be mostly non-statistically significant, but they become positive and statistically significant across all post AS-equations. These results suggest that the AS event has relatively improved the perceptions of the young Egyptians who are characterized by the tendency to be associated with the global community and, thus, who are typically considered to be supportive of international integration of the Egyptian society. The unconditional marginal effects indicate that individuals who are self-recognized by their global association and the corresponding reference individuals have statistically equivalent perceptions on political participation for $P P=3$, political influence of citizens for $P I=3$, and freedom of speech for $F S=3$ in the pre-AS period. These unconditional marginal effects of globalist individuals become positive and statistically significant at the $1 \%$ level in the post AS-period, standing at $12.0,9.4$, and 17.0 percentage points, respectively, ceteris paribus. Also, the perceptions of these self-identified globalist individuals on corruption control and economic performance experience favourable changes in the post-AS period as depicted through the unconditional marginal effects of 15.6 and 13.2 percentage points for $C R=3$ and $E C=3$, respectively, ceteris paribus.

\subsection{Ambitious}

In the empirical model, the variable Ambitious captures the importance for the surveyed young Egyptians to be innovative and prosperous in the society. While this variable is not a precise measure of entrepreneurship, it coarsely proxies for the extent of entrepreneurial orientation. The latter normally prevails in a free economy, and it is often argued to be one important catalyst of economic growth

22 The results underlining favourable perceptions of individuals with secularist inclinations and unfavourable perceptions of individuals with self-recognized Islamic identity are arguably not consistent with the proposition that the AS turned out to be a mere transformation toward Islamism. See Totten et al. (2012) for discussion of different views. 
(Wennekers \& Thurik, 1999; Acs, 2006; Audretsch et al., 2006). The estimated coefficients on this variable indicate that ambition-oriented individuals (as defined through the empirical model) have more favourable perceptions vis-à-vis the reference category in the pre-AS period. However, the perceptions of these individuals experience a relative decline in the post-AS period, becoming equivalently favourable or less favourable than the perceptions of the corresponding reference group. For example, the unconditional marginal effects indicate that farthest ambition-oriented individuals with Ambitious $=3$ have relatively more favourable perceptions on the rule of law for $R L=3$ and on the economic performance for $E C=3$ in the pre-AS period by $3 \times 5.0=15.0$ and $3 \times 7.0=21.0$ percentage points, respectively, ceteris paribus. However, they become statistically non-significant in the post-AS period. Also, the relatively favourable perceptions of these individuals on freedom of speech for $F S=3$ stands at $3 \times 5.2=15.6$ percentage points in the pre-AS period, but it sternly becomes negative and statistically significant at $3 \times(-4.6)=-13.8$ percentage points in the post-AS period, ceteris paribus. These results could signify economic and political uncertainties that face entrepreneurship, and they could be indicative of important implications for economic growth and for the business performance of the private sector. ${ }^{23}$

\section{Conclusion}

Egypt navigated through the waves of the AS event, which generated significant political and social changes. Young Egyptians, who come from different socio-economic backgrounds and socio-political affiliations, had a vital role in the AS uprisings. As such, they naturally yearned for changes in the political system that allow for more political freedom and for effective participation in political life,

\footnotetext{
${ }^{23}$ The empirical findings derived from the unconditional marginal effects are naturally emphasized through the joint marginal effects (see the Appendix). For example, in the case of favourable changes in perceptions, the joint marginal effects exhibit positive (or stronger positive) outcomes for the joint lower pre-AS and higher post-AS categories. Meanwhile, in the case of unfavourable changes, they tend to reveal negative outcomes for the joint lower pre-AS and higher post-AS categories.
} 
and they aspired for a growing economy that suffers less from corruption. This paper aims at analyzing the perceptions of young Egyptians about the AS using a unique dataset extracted from the SAHWA Youth Survey. It lays out the research objective based on initial evidence that highlights the role of socio-economic elements and the significance of cultural and ideological factors in defining and formulating the perceptions of individuals about various political and social events and issues.

This empirical analysis examines the pre-AS and post-AS perceptions of young Egyptians about the AS using various proxies that cover freedom of speech, political participation, political influence of citizens, corruption control, non-fear of arrest, rule of law, and economic performance. The explanatory variables are classified into socio-economic attributes, and value-based characteristics. The empirical analysis is carried out using a bivariate ordered probit model, which allows to jointly examine the determinants of the Egyptian youth's perceptions before and after the AS uprisings.

We find that social values and ideological characteristics matter substantially more than the standard socio-economic attributes in understanding the perceptions of young Egyptians about the AS. Specifically, individuals with secularist and non-traditionalist tendencies have formed more favourable perceptions about the changes that are brought about by the AS event compared to individuals who favour the involvement of religion/religious institutions in state/governmental institutions and to those who are adherent to the conventional Egyptian traditions and norms, respectively. Also, proponents of gender equality have generally formed better perceptions about the AS-related changes. The perceptions of individuals who are culturally self-recognized through the Arab and Islamic identities have mostly experienced unfavourable decline following the AS event. Meanwhile, the perceptions of young Egyptians who are self-recognized to be associated with the global community and, thus, who are typically expected to be supportive of international integration of the Egyptian society, have improved following the AS event. Finally, the perceptions of individuals who place importance on 
being innovative and prosperous in the society have undergone a relative unfavourable decline in the post-AS period.

Our empirical findings suggest significant structural changes in the Egyptian society following the AS event, as reflected through the relative confidence and enthusiasm of more secularist, lesstraditionalist, and more gender-proponent individuals. As such, it seems that the AS has laid down the basis for a (perhaps slow) social and socio-political move towards this set of values. Furthermore, based on the perceptions of Egyptian youth, it appears that the AS has generated unfavourable circumstances for the Arab Nationalism and pan-Islamism ideologies, and propitious socio-economic and sociopolitical conditions for further connection with the global system. There remain significant challenges in the post-AS Egypt, and the outcomes from the AS-related changes could take a relatively long period of time to prevail. Nevertheless, the results signal that the AS may have set a path toward a significant transformation in the Egyptian society. Lastly, it is worth noting that the post-AS transition could be facilitated by easing the concerns of those young Egyptians who hold unfavourable perceptions about the changes that are brought about by the AS event and, thus, by promoting democracy, human rights, and social inclusiveness. 


\section{References}

Abdelrahman, M. (2009). “'With the Islamists?-Sometimes. With the State?-Never!' Cooperation between the Left and Islamists in Egypt." British Journal of Middle Eastern Studies, 36(1), 37-54.

Acar, S., \& Dogruel, F. (2012). "Sources of Inequality in Selected MENA Countries." Structural Change and Economic Dynamics, 23(3), 276-285.

Acemoglu, D., Hassan, T. A., \& Tahoun, A. (2017). "The Power of the Street: Evidence from Egypt's Arab Spring.” The Review of Financial Studies, 31(1), 1-42.

Acs, Z. (2006). "How Is Entrepreneurship Good for Economic Growth?" Innovations: Technology, Governance, Globalization, 1(1), 97-107.

Al-Ali, N. (2012). "Gendering the Arab Spring” Middle East Journal of Culture and Communication, 5(1), 26-31.

Al-Anani, K. (2012). “Islamist Parties Post-Arab Spring.” Mediterranean Politics, 17(3), 466-472.

Al-Anani, K., \& Malik, M. (2013). "Pious Way to Politics: The Rise of Political Salafism in PostMubarak Egypt." Digest of Middle East Studies, 22(1), 57-73.

Anderson, L. (2011). "Demystifying the Arab Spring: Parsing the Differences between Tunisia, Egypt, and Libya." Foreign Affairs, 90(3), 2-7.

Assaad, R., \& Barsoum, G. (2007). "Youth Exclusion in Egypt: In Search of Second Chances." The Middle East Youth Initiative Working Paper No. 2. Wolfensohn Center for Development, Washington, DC.

Audretsch, D. B., Keilbach, M. C., \& Lehmann, E. E. (2006). Entrepreneurship and Economic Growth. Oxford University Press, New York, NY.

Bayat, A. (2013). “The Arab Spring and Its Surprises.” Development and Change, 44(3), 587-601.

Beck, M., \& Hüser, S. (2012). "Political Change in the Middle East: An Attempt to Analyze the 'Arab Spring'." Working Paper No. 203, German Institute of Global and Area Studies, Hamburg, Germany.

Butler, J. S., \& Chatterjee, P. (1997). "Tests of the Specification of Univariate and Bivariate Ordered Probit." The Review of Economics and Statistics, 79(2), 343-347.

Campante, F. R., \& Chor, D. (2012). "Why Was the Arab World Poised for Revolution? Schooling, Economic Opportunities, and the Arab Spring." Journal of Economic Perspectives, 26(2), 167-188.

Caprara, G. V., Barbaranelli, C., \& Zimbardo, P. G. (1999). "Personality Profiles and Political Parties." Political Psychology, 20(1), 175-197.

Conover, P. J. (1984). "The Influence of Group Identifications on Political Perception and Evaluation.” The Journal of Politics, 46(3), 760-785. 
Conover, P. J. (1988). "The Role of Social Groups in Political Thinking." British Journal of Political Science, 18(1), 51-76.

Costello, M., Jenkins, J. C., \& Aly, H. (2015). "Bread, Justice, or Opportunity? The Determinants of the Arab Awakening Protests." World Development, 67, 90-100.

Devarajan, S., \& Ianchovichina, E. (2018). "A Broken Social Contract, Not High Inequality, Led to the Arab Spring." Review of Income and Wealth, forthcoming, DOI: 10.1111/roiw.12288.

El-Samman, A. (2012). Egypt from one Revolution to Another. Gilgamesh Publishing, London, UK.

Frisch, H. (2013). “The Egyptian Army and Egypt's 'Spring'.” Journal of Strategic Studies, 36(2), 180204.

Ghanem, H. (2018). The Arab Spring Five Years Later: Toward Greater Inclusiveness. Brookings Institution Press, Washington, DC.

Glasius, M., \& Pleyers, G. (2013). "The Global Moment of 2011: Democracy, Social Justice and Dignity." Development and Change, 44(3), 547-567.

Granberg, D. (1985). “An Anomaly in Political Perception.” Public Opinion Quarterly, 49(4), 504516.

Greene, W. H. (2012). Econometric Analysis. Prentice Hall, Upper Saddle River, NJ.

Greene, W. H., \& Hensher, D. A. (2010). Modeling Ordered Choices: A Primer. Cambridge University Press, Cambridge, UK.

Hamid, S. (2014). "Political Party Development Before and After the Arab Spring." In: M. Kamrava (Ed.), Beyond the Arab Spring: The Evolving Ruling Bargain in the Arab World, (pp. 131-150). Hurst Publishers, London, UK.

Hassine, N. B. (2015). “Economic Inequality in the Arab Region.” World Development, 66, 532-556.

Hoffman, M., \& Jamal, A. (2012). "The Youth and the Arab Spring: Cohort Differences and Similarities." Middle East Law and Governance, 4(1), 168-188.

Karshenas, M., Moghadam, V. M., \& Alami, R. (2014). "Social Policy after the Arab Spring: States and Social Rights in the MENA Region." World Development, 64, 726-739.

Kuhn, R. (2012). "On the Role of Human Development in the Arab Spring." Population and Development Review, 38(4), 649-683.

LaGraffe, D. (2012). "The Youth Bulge in Egypt: An Intersection of Demographics, Security, and the Arab Spring." Journal of Strategic Security, 5(2), 65-80. 
Lesch, D., \& Haas, M. L. (2016). The Arab Spring: The Hope and Reality of the Uprisings. Westview Press, Boulder, CO.

Little, D. (1988). "The New Frontier on the Nile: JFK, Nasser, and Arab Nationalism." The Journal of American History, 75(2), 501-527.

Marfleet, P. (2016). Egypt: Contested Revolution .University of Chicago Press, Chicago, IL.

Moghadam, V. M. (2013). "What Is Democracy? Promises and Perils of the Arab Spring." Current Sociology, 61(4), 393-408.

Moghadam, V. M. (2014). "Modernising Women and Democratisation after the Arab Spring." The Journal of North African Studies, 19(2), 137-142.

Mulderig, M. C. (2013). "An Uncertain Future: Youth Frustration and the Arab Spring." The Pardee Papers No. 16, The Frederick S. Pardee Center for the Study of the Longer-Range Future, Boston University, Boston. MA.

Nogee, P., \& Levin, M. B. (1958). "Some Determinants of Political Attitudes among College Voters." Public Opinion Quarterly, 22(4), 449-463.

Paciello, M. C., \& Pioppi, D. (2018). "Is Arab Youth the Problem (or the Solution)? Assessing the Arab Human Development Report 2016." Development and Change, 49(2), 629-643.

Refaei, M. M. (2015). Political Participation in Egypt: Perceptions and Practice. Baseera, Cairo, Egypt.

Rougier, E. (2016). "Fire in Cairo: Authoritarian-Redistributive Social Contracts, Structural Change, and the Arab Spring." World Development, 78, 148-171.

Sajaia, Z. (2008). "Maximum Likelihood Estimation of a Bivariate Ordered Probit Model: Implementation and Monte Carlo Simulations." The Stata Journal, 4(2), 1-18.

Sayed, M. (2013). Perception of Young People towards Political Participation in Liberal Political Parties in Egypt Post the 25th January Revolution: A Qualitative Study. American University of Cairo, Cairo, Egypt.

Schoon, I., \& Cheng, H. (2011). "Determinants of Political Trust: A Lifetime Learning Model." Developmental Psychology, 47(3), 619-631.

Singerman, D. (2013). "Youth, Gender, and Dignity in the Egyptian Uprising." Journal of Middle East Women's Studies, 9(3), 1-27.

Totten, M. J., Schenker, D., \& Abdul-Hussain, H. (2012). “Arab Spring or Islamist Winter? Three Views." World Affairs, 174(5), 23-42.

United Nations Development Programme (UNDP). (2016). Arab Human Development Report 2016: Youth and the Prospects for Human Development in a Changing Reality. UNDP, New York, NY. 
Vecchione, M., \& Caprara, G. V. (2009). "Personality Determinants of Political Participation: The Contribution of Traits and Self-Efficacy Beliefs." Personality and Individual Differences, 46(4), 487492.

Verme, P., Milanovic, B., Al-Shawarby, S., El Tawila, S., Gadallah, M., \& El-Majeed, E. A. A. (2014). Inside Inequality in the Arab Republic of Egypt: Facts and Perceptions across People, Time, and Space. World Bank Publications, Washington, DC.

Volpi, F., \& Stein, E. (2015). "Islamism and the State after the Arab Uprisings: Between People Power and State Power." Democratization, 22(2), 276-293.

Wennekers, S., \& Thurik, R. (1999). "Linking Entrepreneurship and Economic Growth." Small Business Economics, 13(1), 27-56.

Winckler, O. (2013). “The Arab Spring: Socioeconomic Aspects.” Middle East Policy, 20(4), 68-87. 
Table 1. Summary Statistics - Ordinal Dependent Variables

\begin{tabular}{|c|c|c|c|c|c|c|}
\hline & (i) & (ii) & (iii) & (iv) & $(\mathrm{v})$ & (vi) \\
\hline & \multicolumn{3}{|c|}{ Pre-Arab Spring (in \%) } & \multicolumn{3}{|c|}{ Post-Arab Spring (in \%) } \\
\hline & $\mathrm{ODV}=1$ & $\mathrm{ODV}=2$ & $\mathrm{ODV}=3$ & $\mathrm{ODV}=1$ & $\mathrm{ODV}=2$ & $\mathrm{ODV}=3$ \\
\hline Political Participation & 668.48 & 13.10 & 18.43 & 36.80 & 19.19 & 44.01 \\
\hline Political Influence of Citizens & 84.01 & 7.56 & 8.43 & 59.09 & 18.73 & 22.18 \\
\hline Freedom of Speech & 69.70 & 11.93 & 18.38 & 34.97 & 20.00 & 45.03 \\
\hline Non-Fear of Arrest & 76.29 & 12.13 & 11.57 & 53.10 & 20.00 & 26.90 \\
\hline Rule of Law & 57.66 & 17.92 & 24.42 & 30.05 & 21.98 & 47.97 \\
\hline Corruption Control & 77.92 & 10.96 & 11.12 & 48.88 & 18.98 & 32.13 \\
\hline Economic Performance & 69.39 & 12.69 & 17.92 & 50.05 & 22.54 & 27.41 \\
\hline
\end{tabular}

Notes: ODV denotes Ordinal Dependent Variable. 
Table 2. Summary Statistics - Explanatory Variables

\begin{tabular}{l||cc}
\hline \hline & (i) & (ii) \\
\hline \hline & & Mean \\
\hline Value-Based Characteristics & 1.381 & 0.710 \\
Gecularist & 1.537 & 0.425 \\
Nonder Equality Proponent & 0.091 & 0.287 \\
Self-Identity: Global & 0.070 & 0.254 \\
Self-Identity: Arab & 0.115 & 0.319 \\
Self-Identity: Islamic & 0.101 & 0.301 \\
Ambitious & 2.104 & 0.980 \\
\hline \hline Socio-Economic Characteristics & & \\
\hline \hline Male & 0.497 & 0.500 \\
Age & 22.290 & 3.779 \\
Income & 19.825 & 44.259 \\
No education & 0.049 & 0.215 \\
School & 0.705 & 0.456 \\
University & 0.246 & 0.431 \\
Married & 0.642 & 0.479 \\
Employed & 0.338 & 0.473 \\
Urban Residence & 0.383 & 0.486 \\
\hline \hline
\end{tabular}




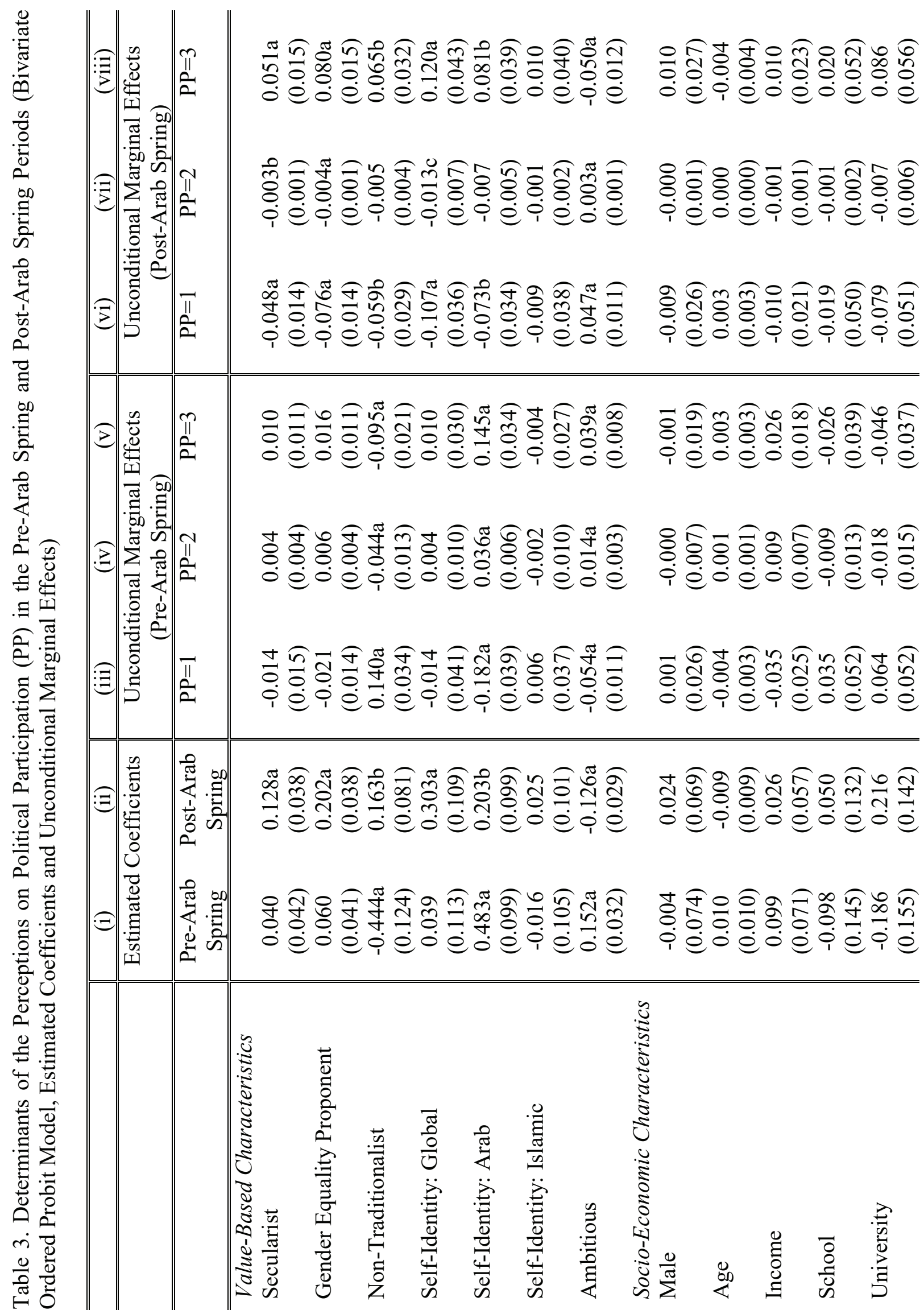


(|)

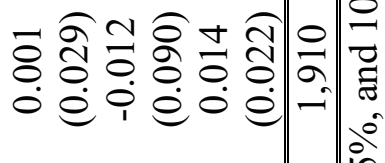

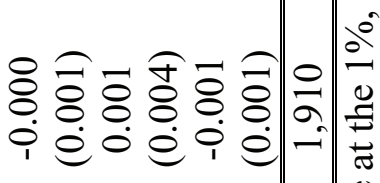

ธิ宀

i

考

○ें

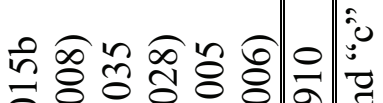

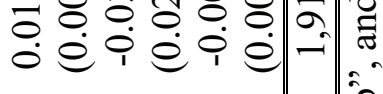

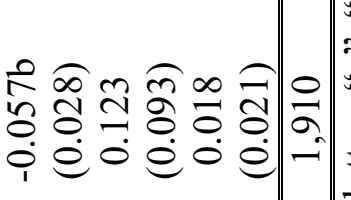

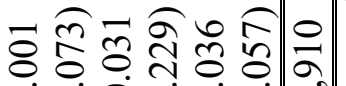

$\circ$ e

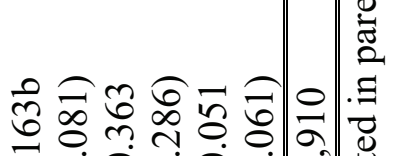

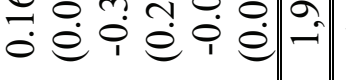

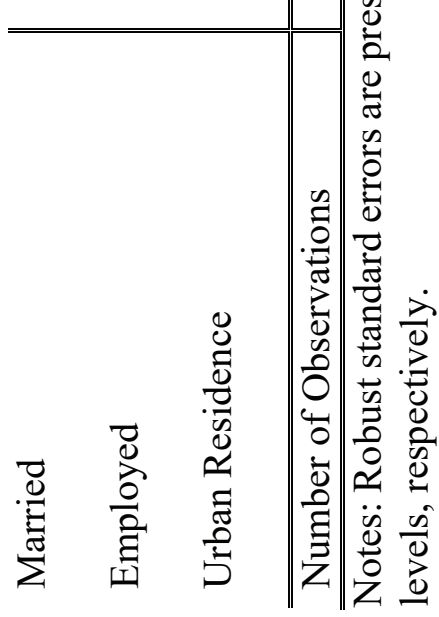




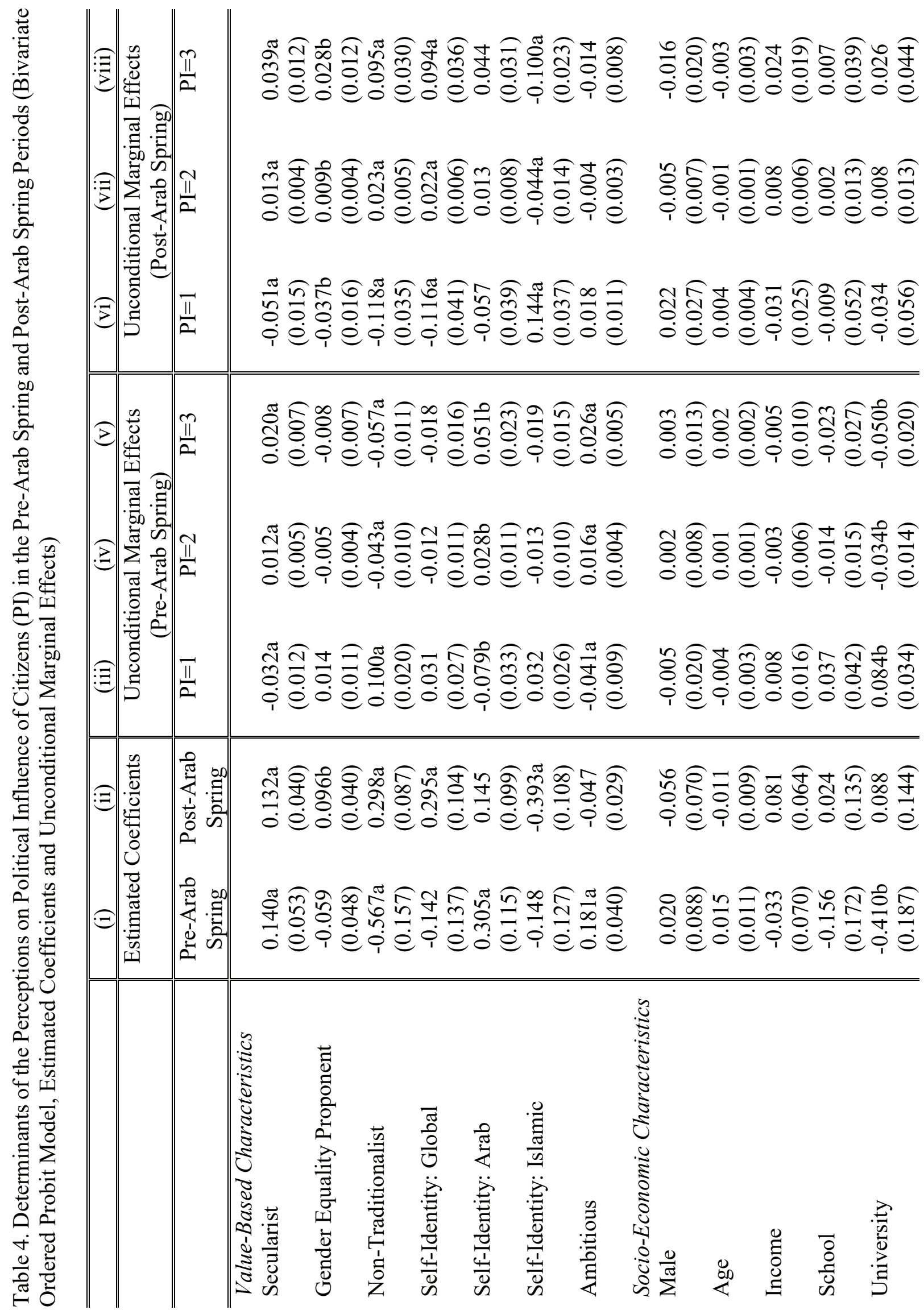




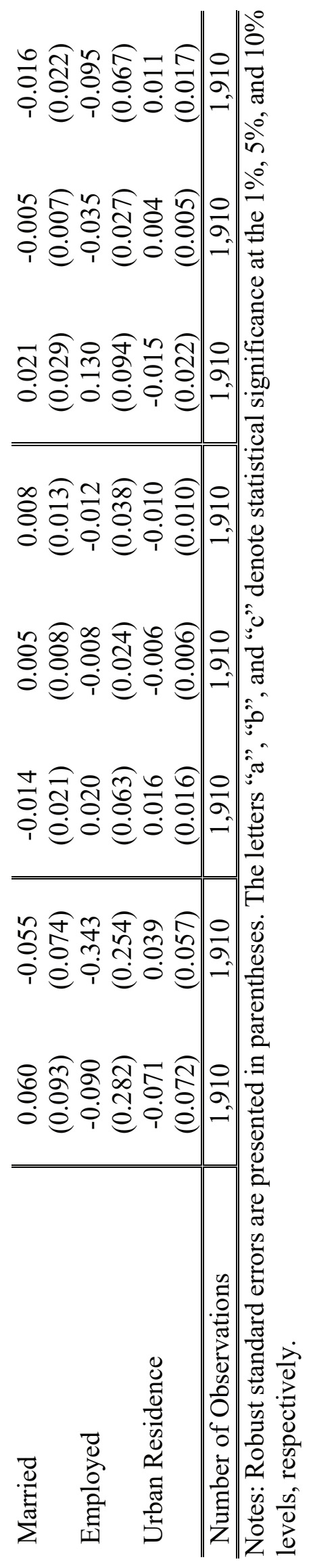




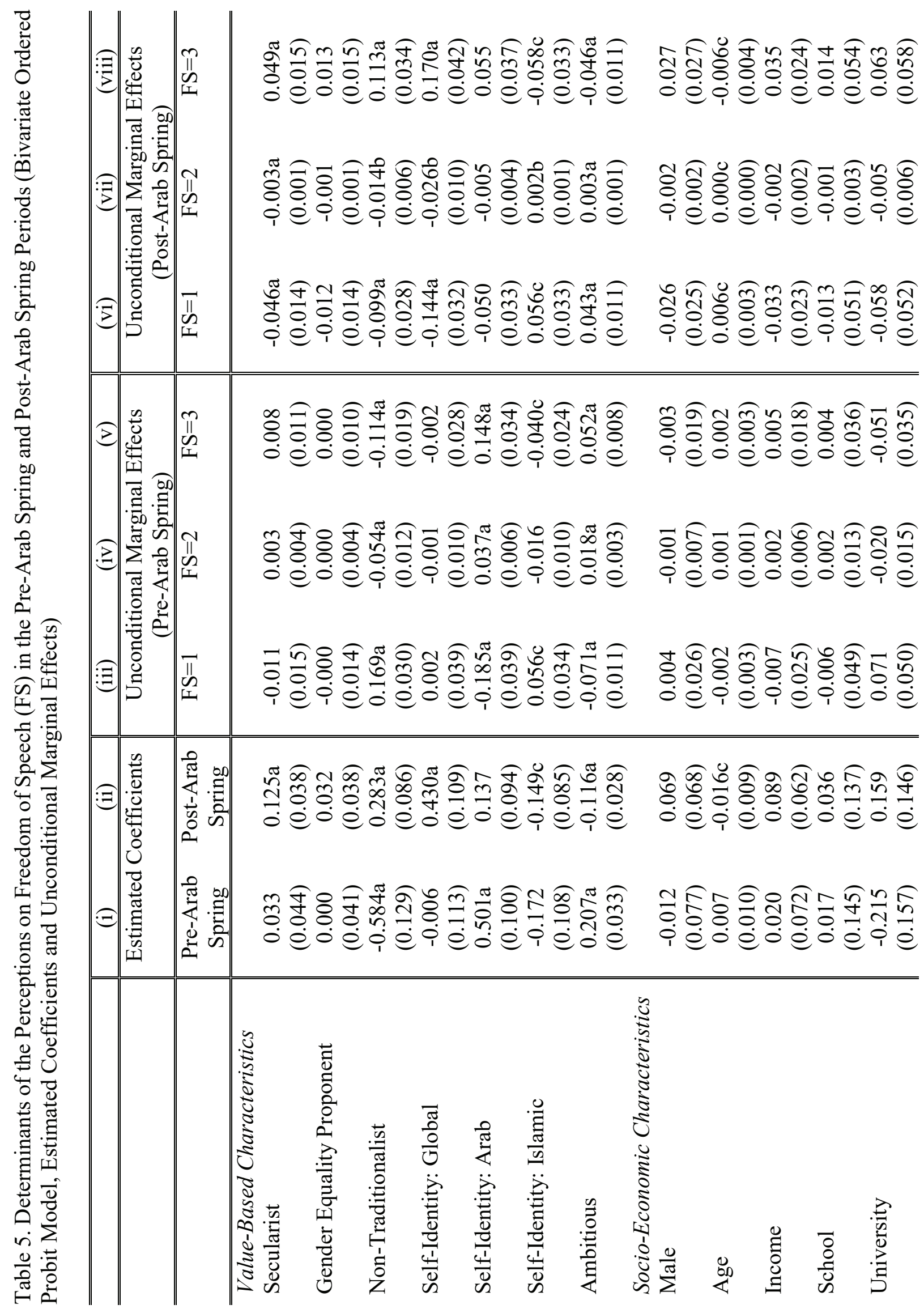




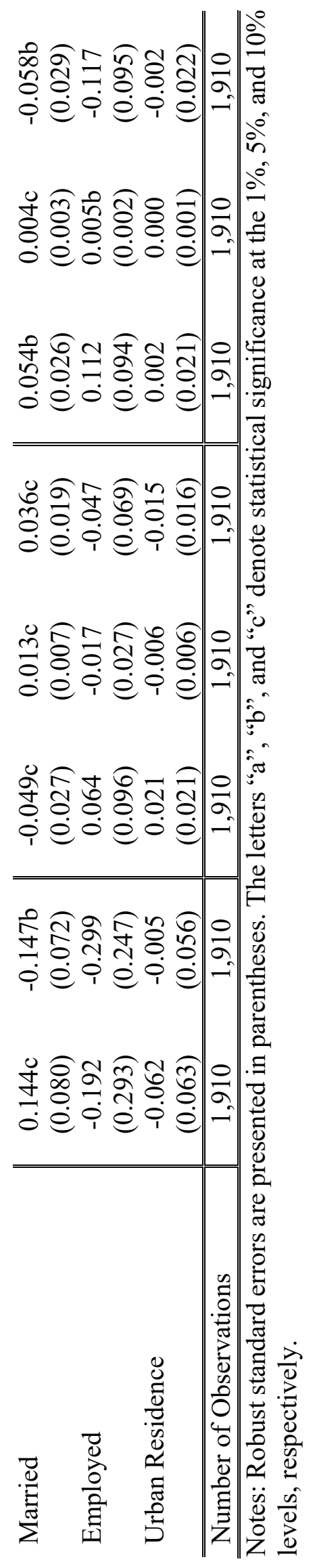




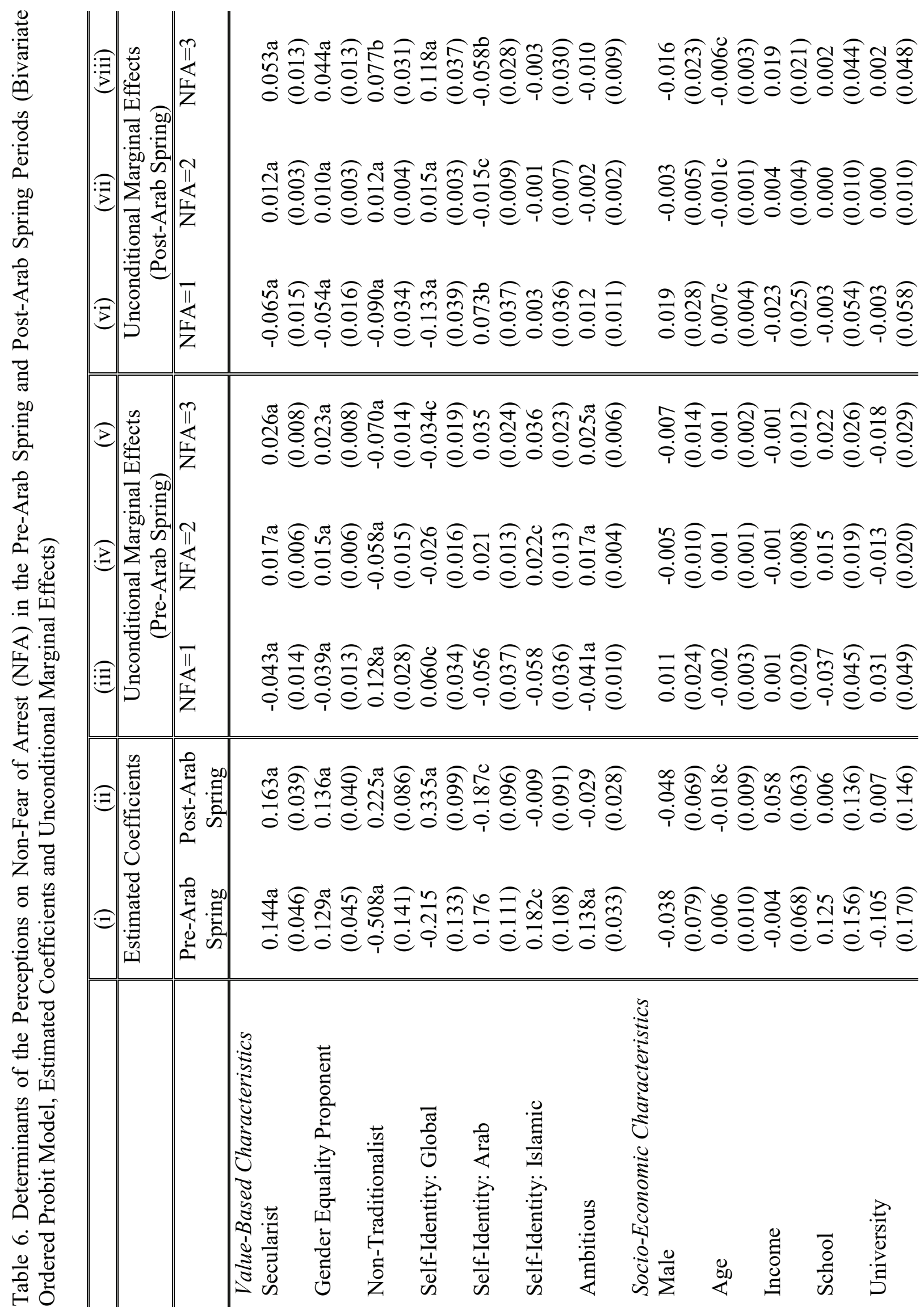




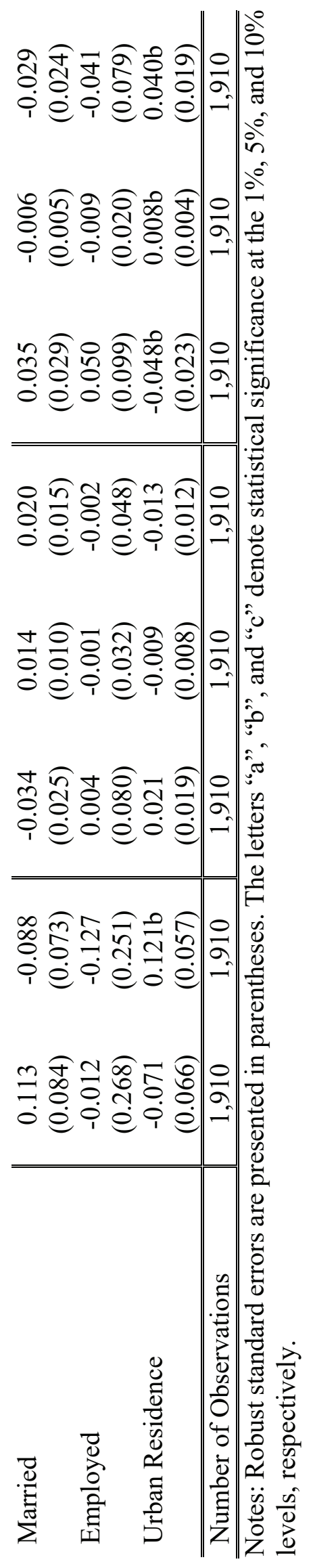




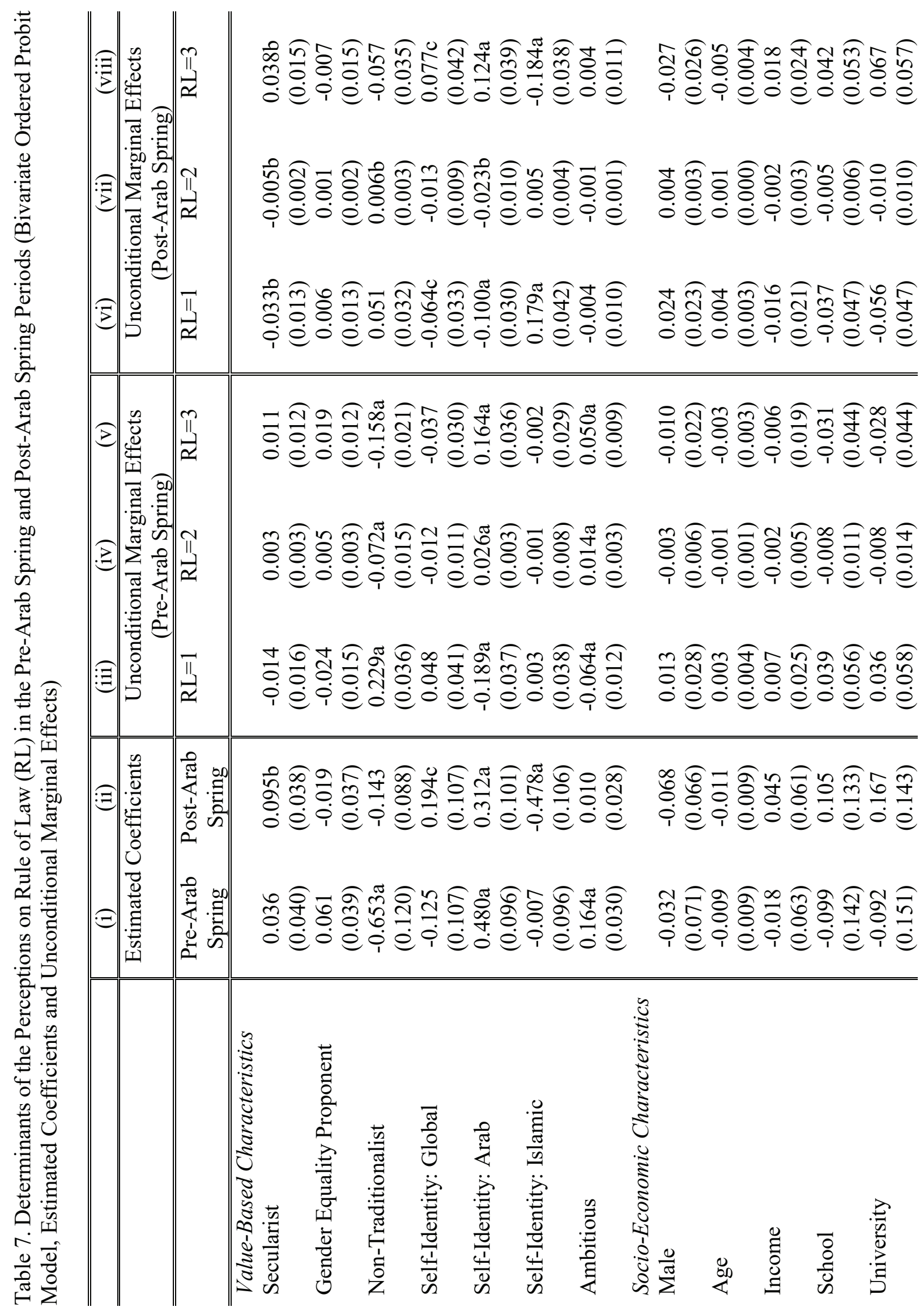




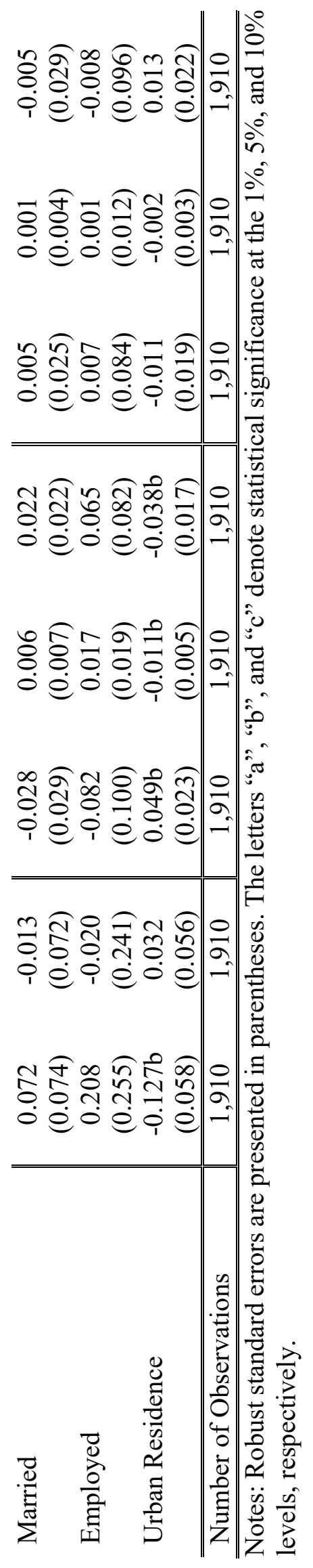




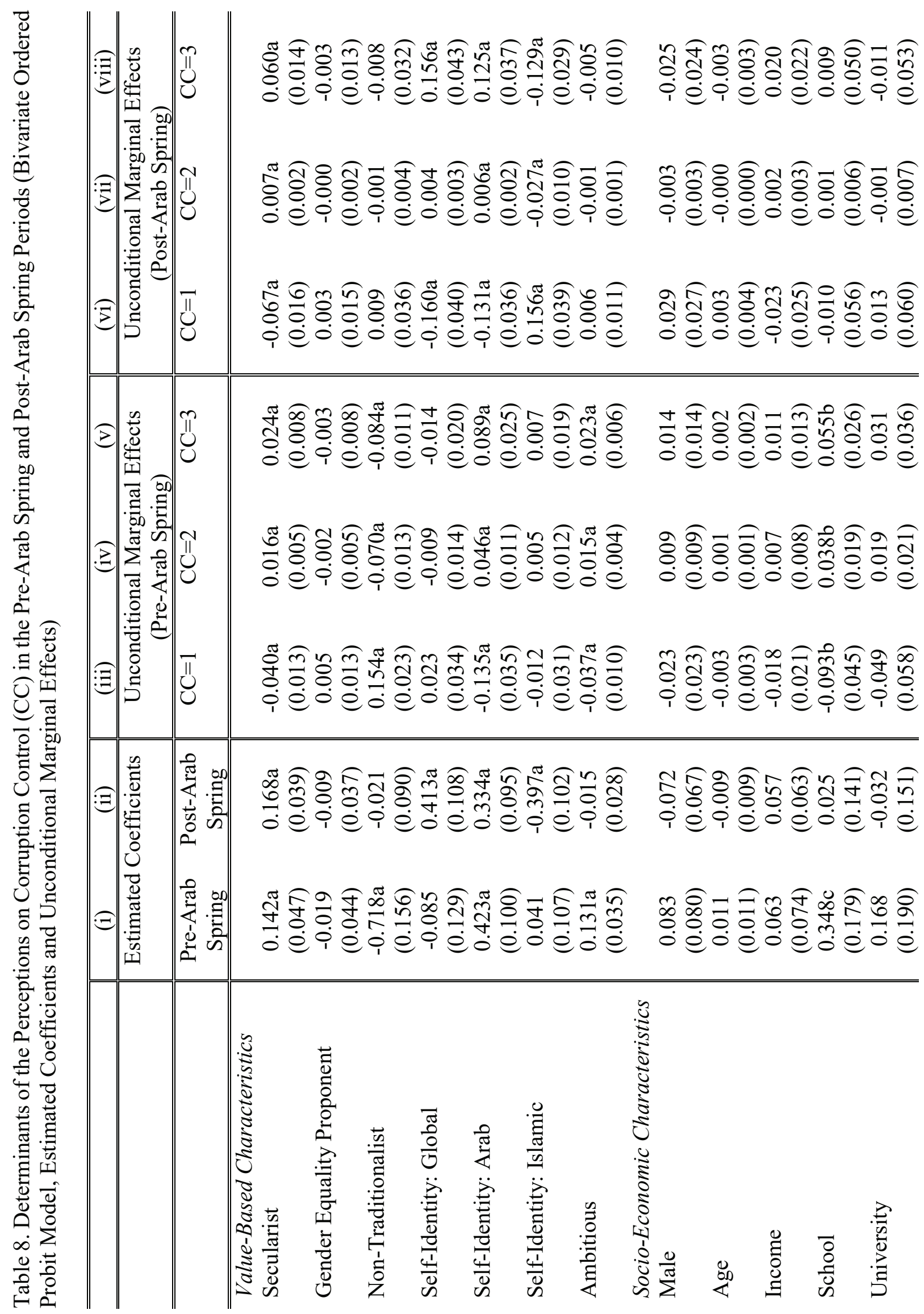




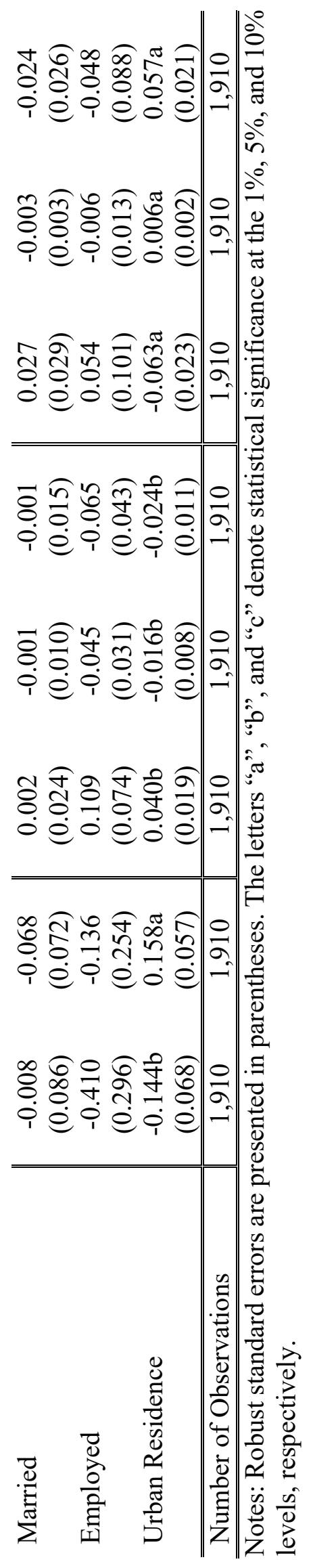




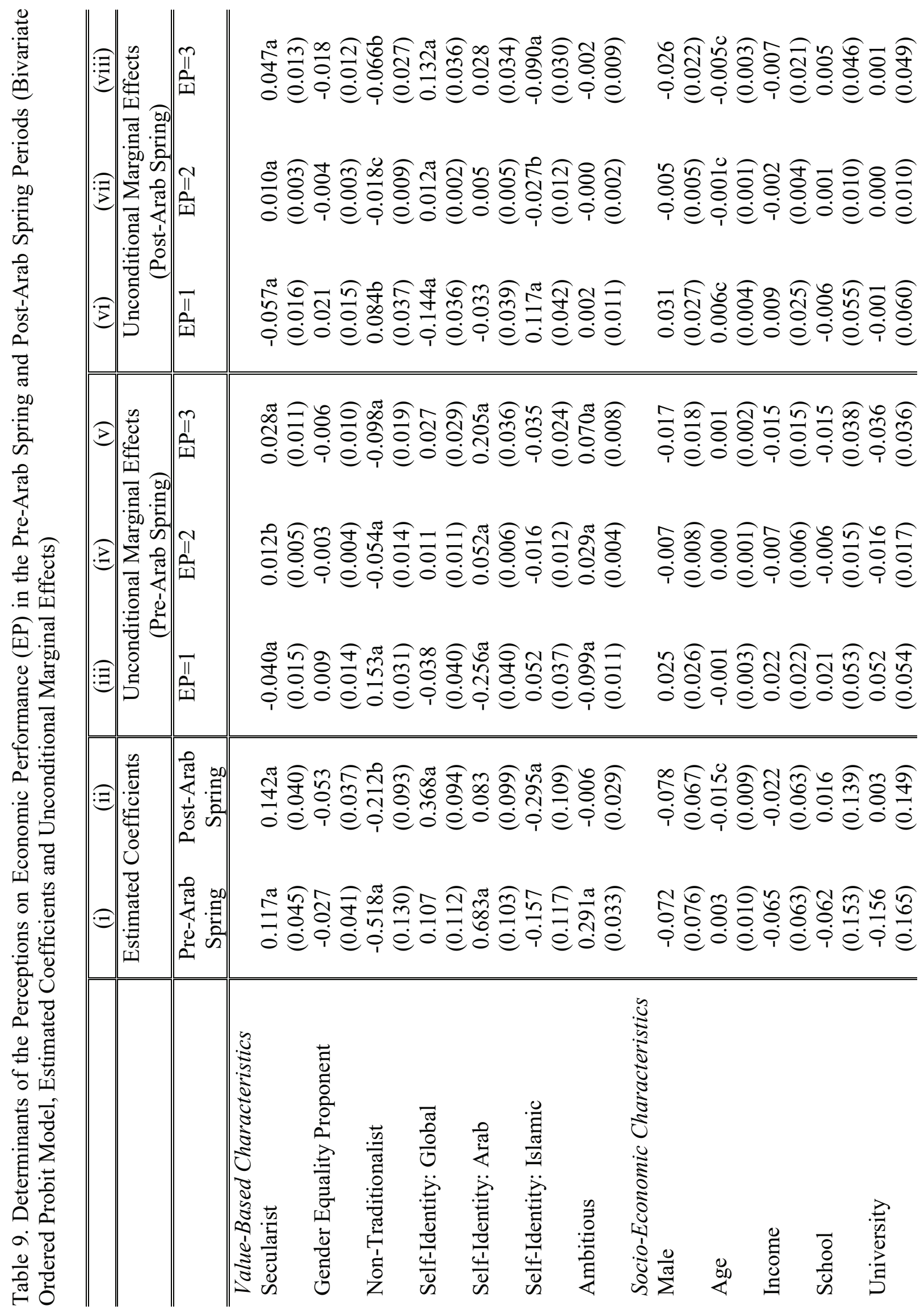




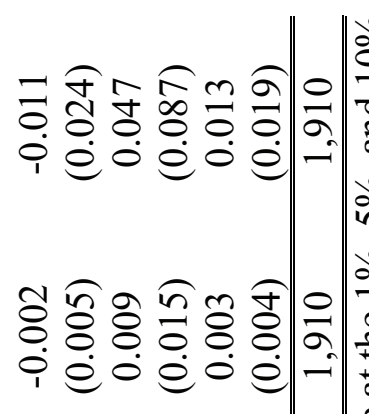

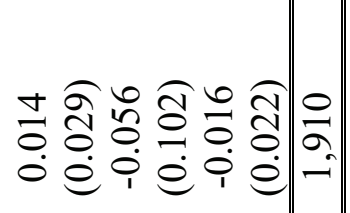

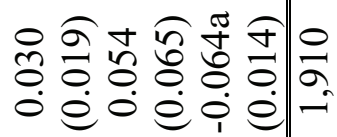

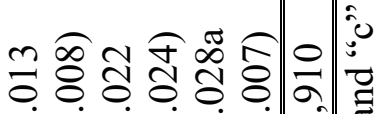

\begin{tabular}{cccccc|}
0 & 0 & 0 & 0 & 0 & 0 \\
0 & 0 & 0 & 0 & 0 & 0
\end{tabular}

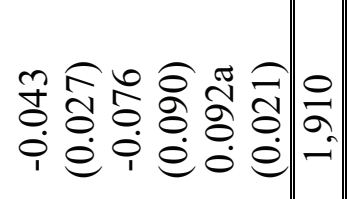

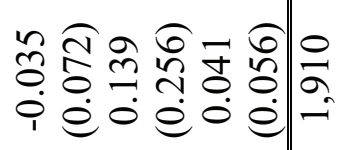

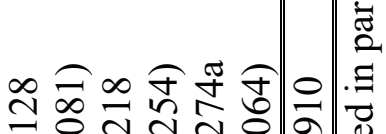

문

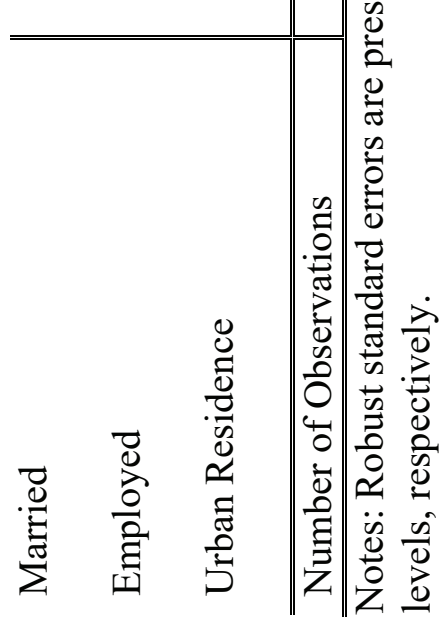




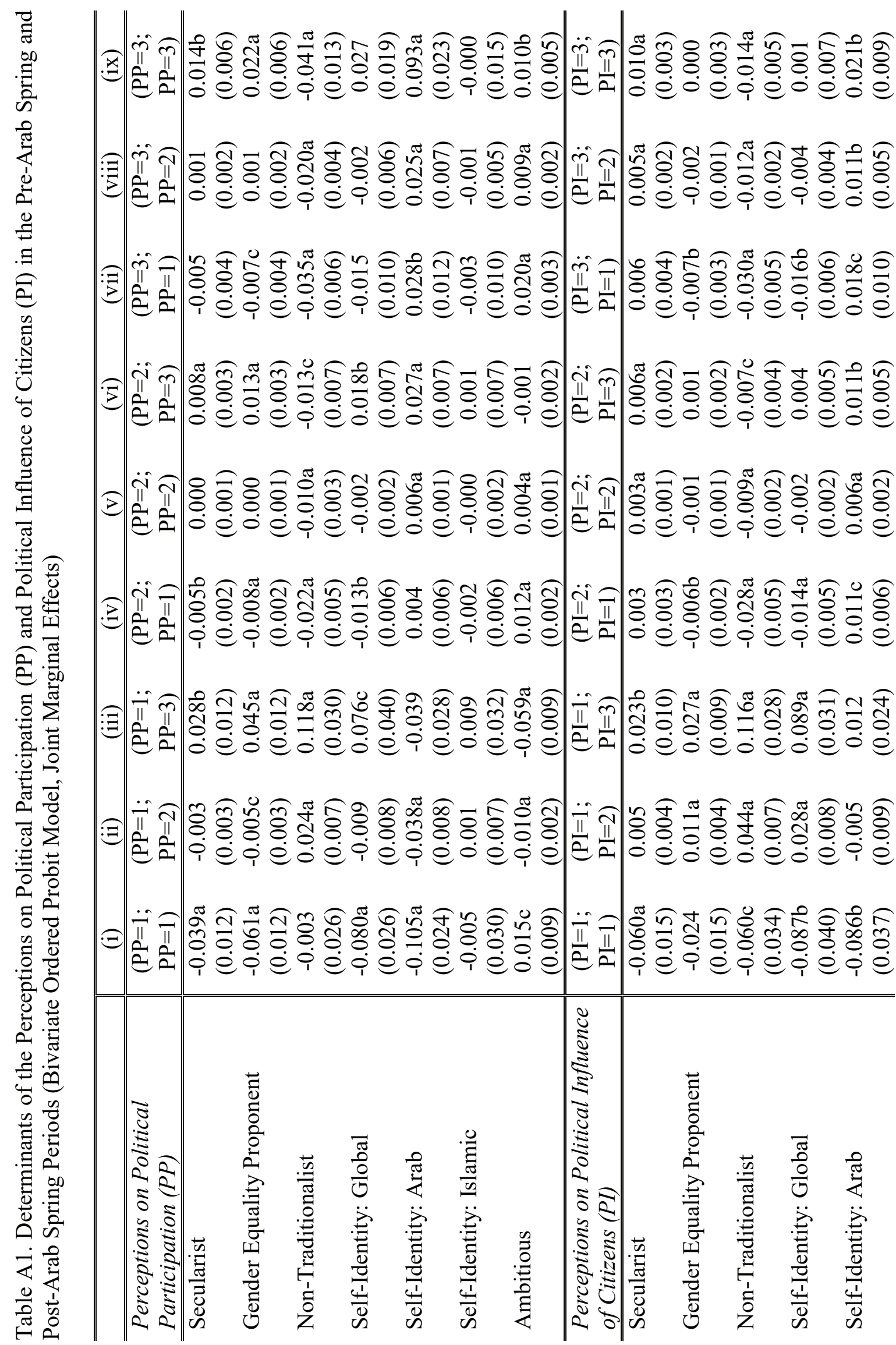


ชิ

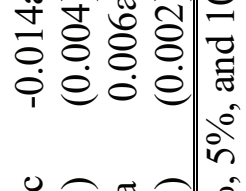

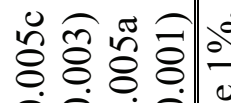

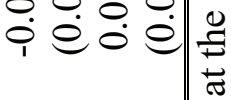

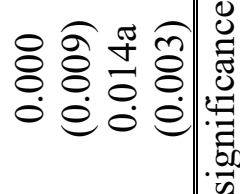

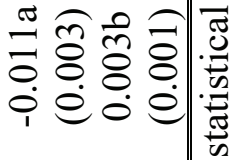

ถి ิิ

ie 0 i

\&े

$\therefore$ 过定: 0.0

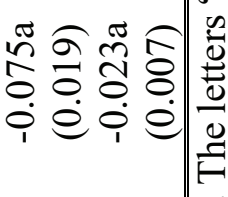

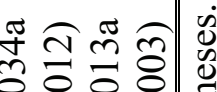

i

ㅇํㄹ

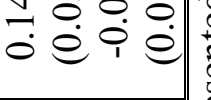

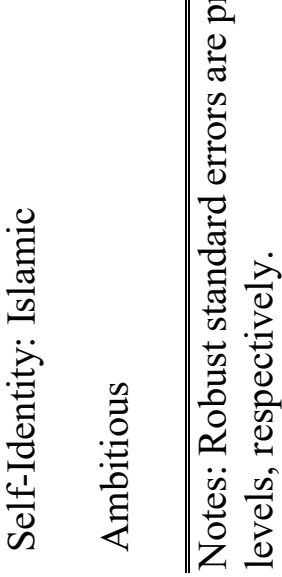




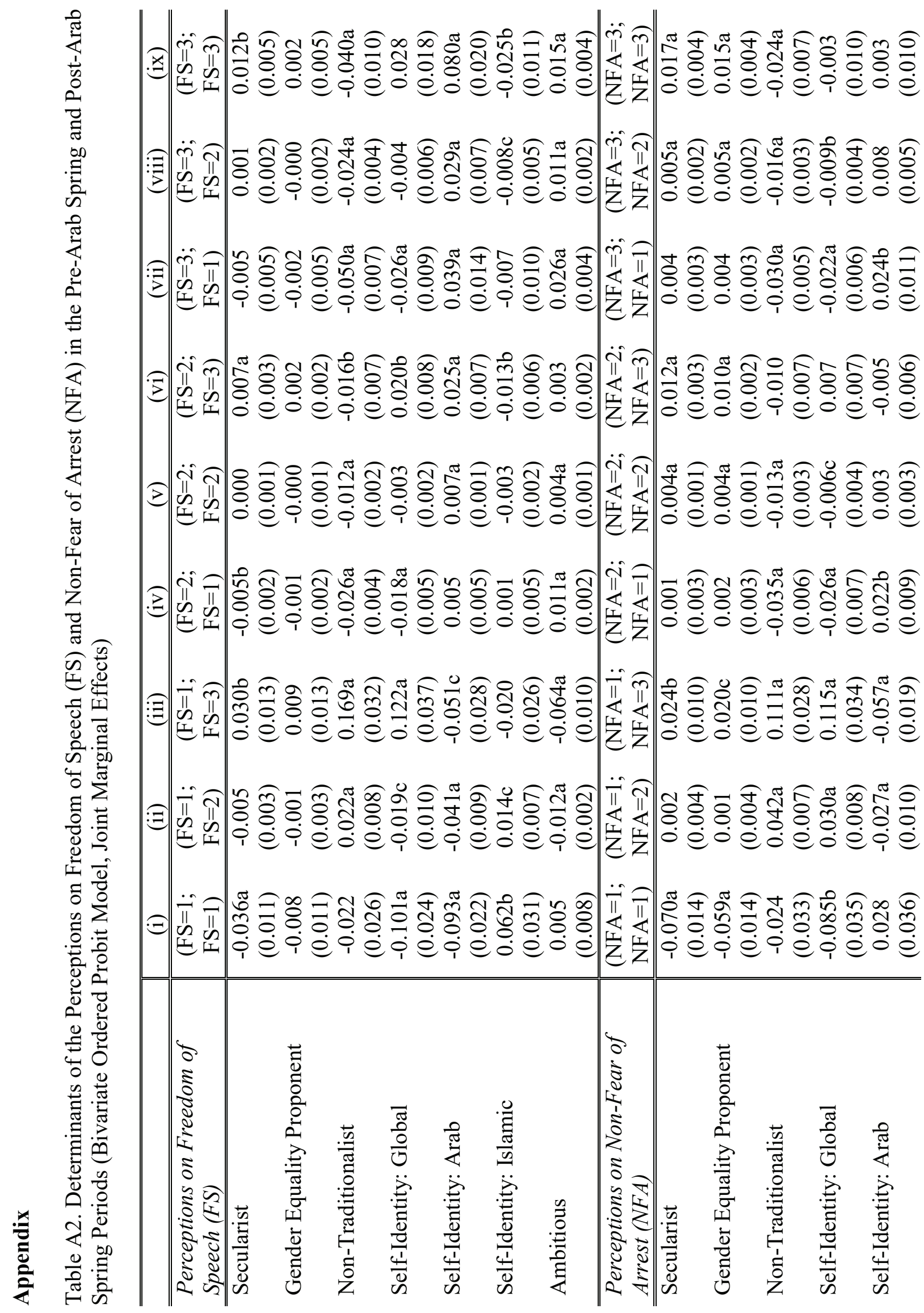




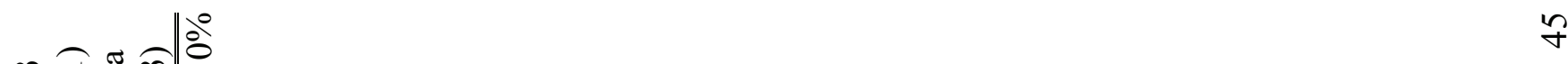

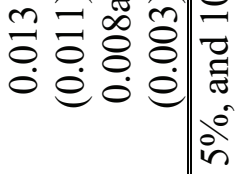

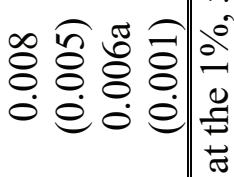

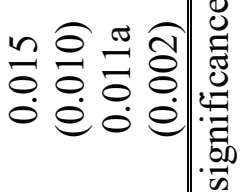

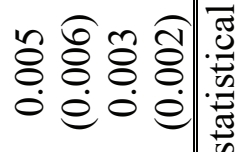

응

$\ddot{0} \dot{e} \dot{0} \dot{e}$

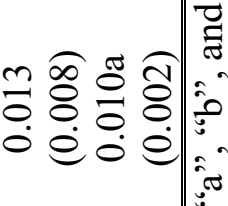

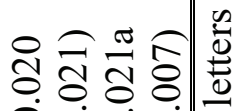

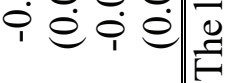

m

i

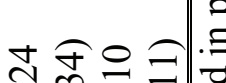

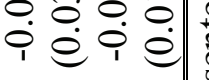

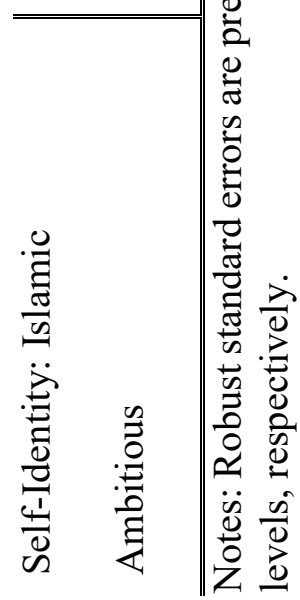




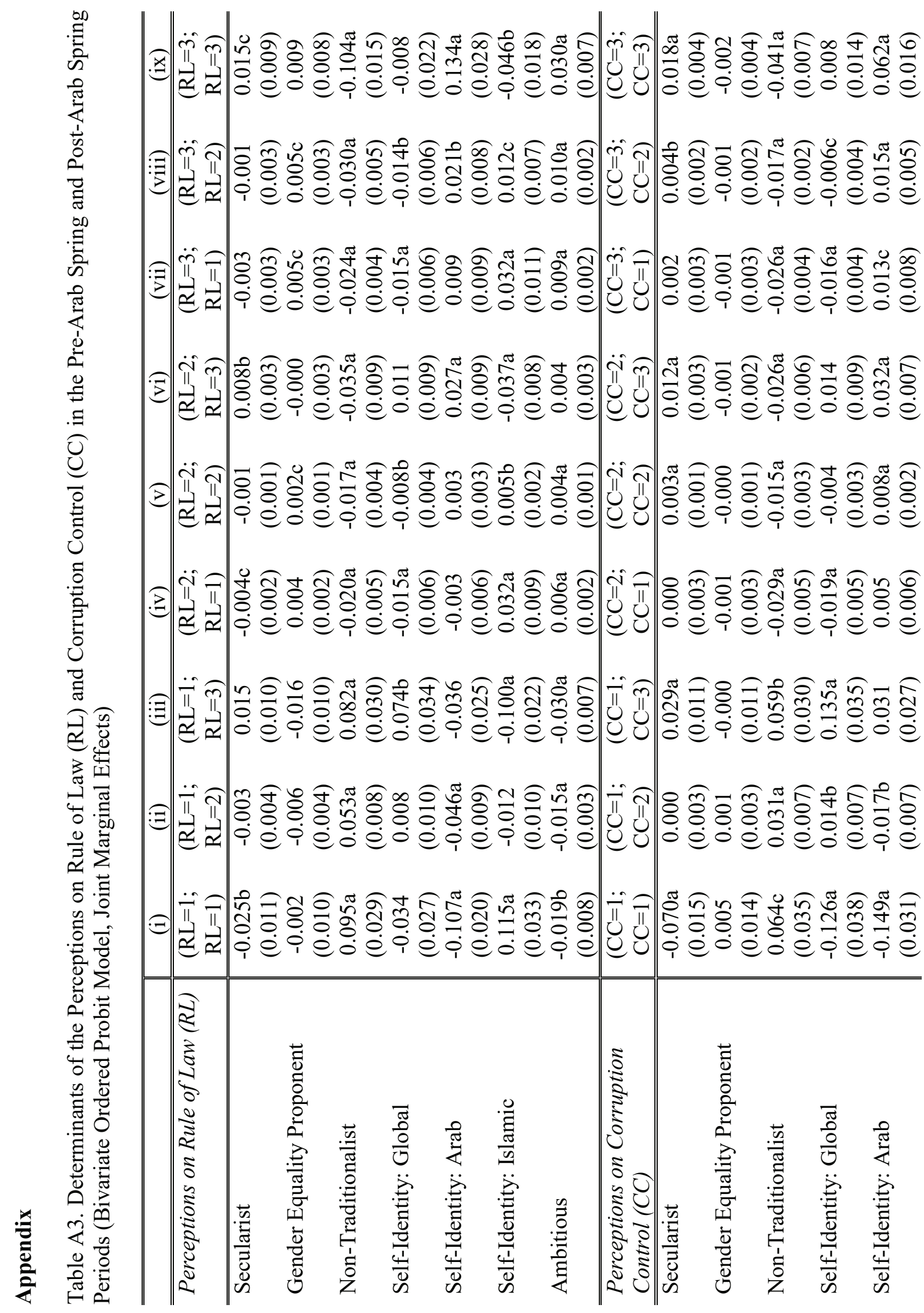


ำ

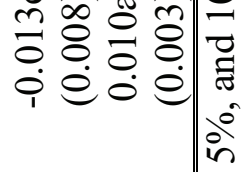

ô.

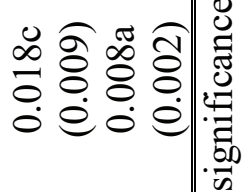

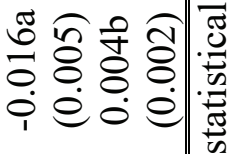

客

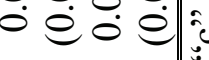

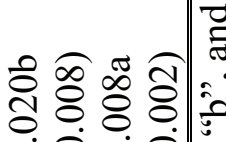

0.0 .0 .0$.

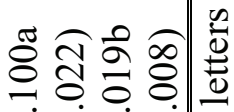

i $\dot{\varphi} \dot{\varphi} \dot{\ominus}$

oึ

i ei é

응의

○े

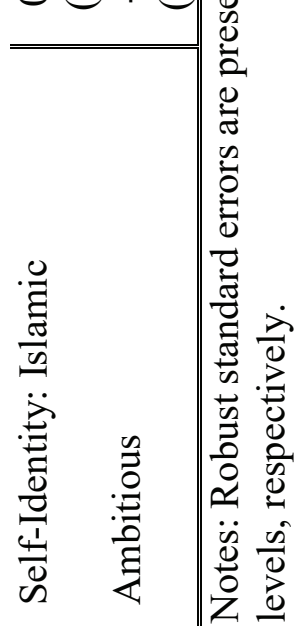




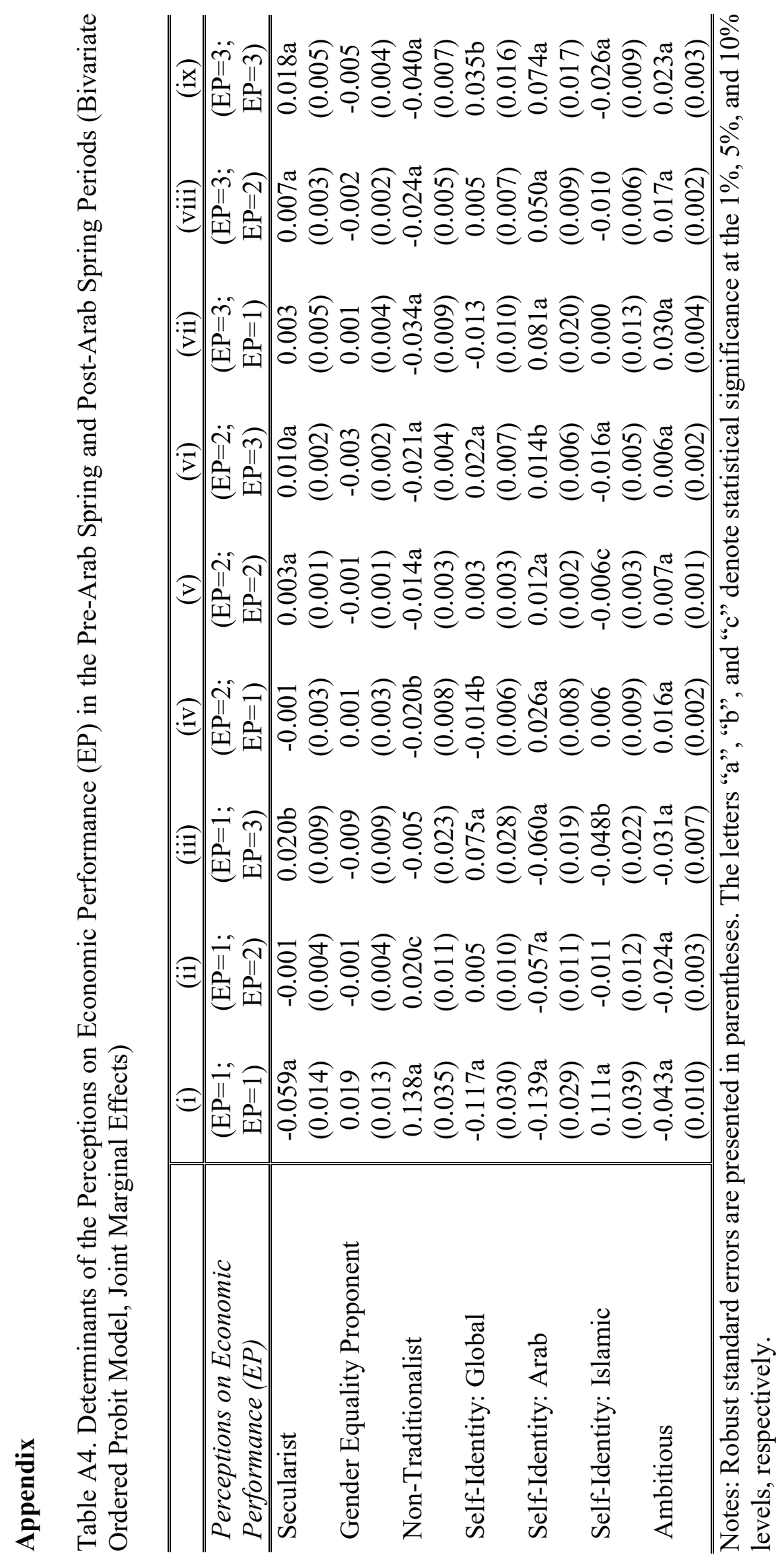

